\title{
La Anunciación del Monasterio de Caleruega (Burgos): contextualización en la Baja Edad Media peninsular
}

\author{
Tomás IBÁÑEz PALOMO \\ Universidad Complutense de Madrid \\ tibanez@ucm.es
}

Recibido: 28-02-2015

Aceptado: 08-07-2015

\section{RESUMEN}

La Anunciación del Monasterio de Santo Domingo de Caleruega, fundado por Alfonso X el Sabio, ha permanecido prácticamente olvidada por la historiografía nacional. Aislado tras los muros de la clausura, el grupo escultórico presenta una particularidad que, durante mucho tiempo, no fue analizada convenientemente: la Virgen está embarazada. La cantidad de ejemplos contabilizados de la misma naturaleza demuestra que esta clase de representaciones fue habitual, durante la Baja Edad Media, en algunos reinos de la península ibérica. Con un enfoque fundamentalmente iconográfico pero sin renunciar a otra clase de aproximaciones, el presente artículo pretende estudiar en profundidad la singularidad de la Anunciación calerogana que, al mismo tiempo, se convierte en el punto de partida para un análisis global de esta variante de la Salutación Angélica.

Palabras clave: Arte medieval. Iconografía. Anunciación Preñada. Escultura gótica. Arte español. Arte portugués.

\section{The Annunciation from the Monastery of Caleruega (Burgos): Contextualisation in the Late Middle Ages of the Iberian Peninsula}

\begin{abstract}
The Annunciation from the Monastery of Santo Domingo of Caleruega, founded by Alfonso X the Wise, has remained virtually forgotten by the Spanish historiography. Isolated behind the walls of the cloister, the sculpture group presents a particularity that hasn't been properly analyzed for too long: the Virgin is pregnant. The amount of recorded examples of the same nature shows that this kind of representations was common in some kingdoms of the Iberian Peninsula during the Late Middle Ages. From an essentially iconographic perspective, but without giving up further approaches, this paper provides an in-depth study on the singularity of the Annunciation from Caleruega. At the same time, it becomes the starting point for a comprehensive analysis of this variant of the Angelic Salutation.
\end{abstract}

Key words: Medieval Art. Iconography. Pregnant Annunciation. Gothic Sculpture. Spanish Art. Portuguese Art. 
Sumario: 1. Introducción. 2. El estudio de las Anunciaciones Preñadas en la historiografía española. 3. Historia de la obra: cronología y ubicaciones conocidas. 4. Aspectos técnicos: características formales y estado de conservación. 5. Análisis iconográfico. 6. Las variantes iconográficas de Castilla, Galicia y Portugal. 7. Conclusiones.

\section{Introducción}

En sus más de setecientos años de historia, el monasterio ${ }^{1}$ de Caleruega ha sido objeto de numerosas reformas y restauraciones. Como corresponde a un edificio habitado durante tanto tiempo, las necesidades de sus moradores determinaron las intervenciones que alteraron para siempre el entorno original de sus obras de arte. Tal es el caso del grupo de la Anunciación (Fig. 1) que, debido a su ubicación dentro de la clausura, ha pasado inadvertido durante años y ahora, cuando los investigadores se acercan a él por primera vez, lo encontramos expuesto en una de las antiguas salas del claustro, completamente descontextualizado. Allí, a pesar de estar rodeado por el resto de tesoros artísticos del monasterio, esta pareja de esculturas siempre acapara la atención del visitante.

Quienes la contemplan coinciden en resaltar la indiscutible belleza de sus formas, el delicado trabajo del artista y la armonía que irradia el conjunto. Sin embargo, un aspecto destaca por encima de todos los demás: María está embarazada. La evidente contradicción que supone representar a la Virgen en avanzado estado de gestación al tiempo que es informada de su futura maternidad no ha sido analizada hasta fechas relativamente recientes. Además, el estudio de esta variedad de la Salutación Angélica ha estado supeditado al de las Vírgenes de la Expectación -imágenes independientes que aluden a la gravidez de María- con las que, en ocasiones, se han confundido esculturas inicialmente acompañadas por Gabriel.

Quizá por ello, estos grupos, realizados en su mayoría durante la Baja Edad Media, continúan siendo grandes desconocidos y, al encontrarse frente a uno de ellos, son muchos los que creen hallarse ante un caso excepcional. Sin embargo, las cifras nos confirman que esta manera de plasmar la Anunciación fue mucho más habitual de lo que se piensa. Durante la realización de esta investigación hemos contabilizado un total de veintiocho ejemplos españoles. Asimismo, el número no debió de ser escaso en Portugal. ${ }^{2}$ Teniendo en cuenta que la Iglesia de los siglos XVIII y XIX recomendó

1 En este artículo empleamos los términos «monasterio» y «convento» siguiendo el criterio utilizado por Mercedes Pérez Vidal en su tesis doctoral, donde la autora reserva el primero para referirse a los edificios de la rama femenina de la Orden de Predicadores, al menos durante la Edad Media. PÉREZ VIDAL, Mercedes: Arte y arquitectura de los monasterios de la Orden de Predicadores de la "provincia de España». Desde los orígenes hasta la reforma (1218-1506). Tesis doctoral. Director: Eduardo Carrero Santamaría. Universidad de Oviedo, Departamento de Historia del Arte y Musicología, 2013, pp. 20-23. Disponible en web: https://www. educacion.gob.es/teseo/imprimirFicheroTesis.do?fichero=39415 [última consulta: 13/02/2015]. No obstante, se trata de una cuestión compleja que ha sido abordada por diversos autores sin haberse llegado a un consenso al respecto.

2 Como indicaremos más adelante, el estudio de los grupos portugueses es complejo por la dificultad que supone acceder a la bibliografía lusa. A la falta de estudios sobre la materia en las bibliotecas de nuestro país, debemos añadir el hecho de que en Portugal se denomina por igual, bajo la advocación de Nossa Senhora do $O$, tanto a las Vírgenes encinta independientes como a las que forman parte de una Anunciación. De esta 


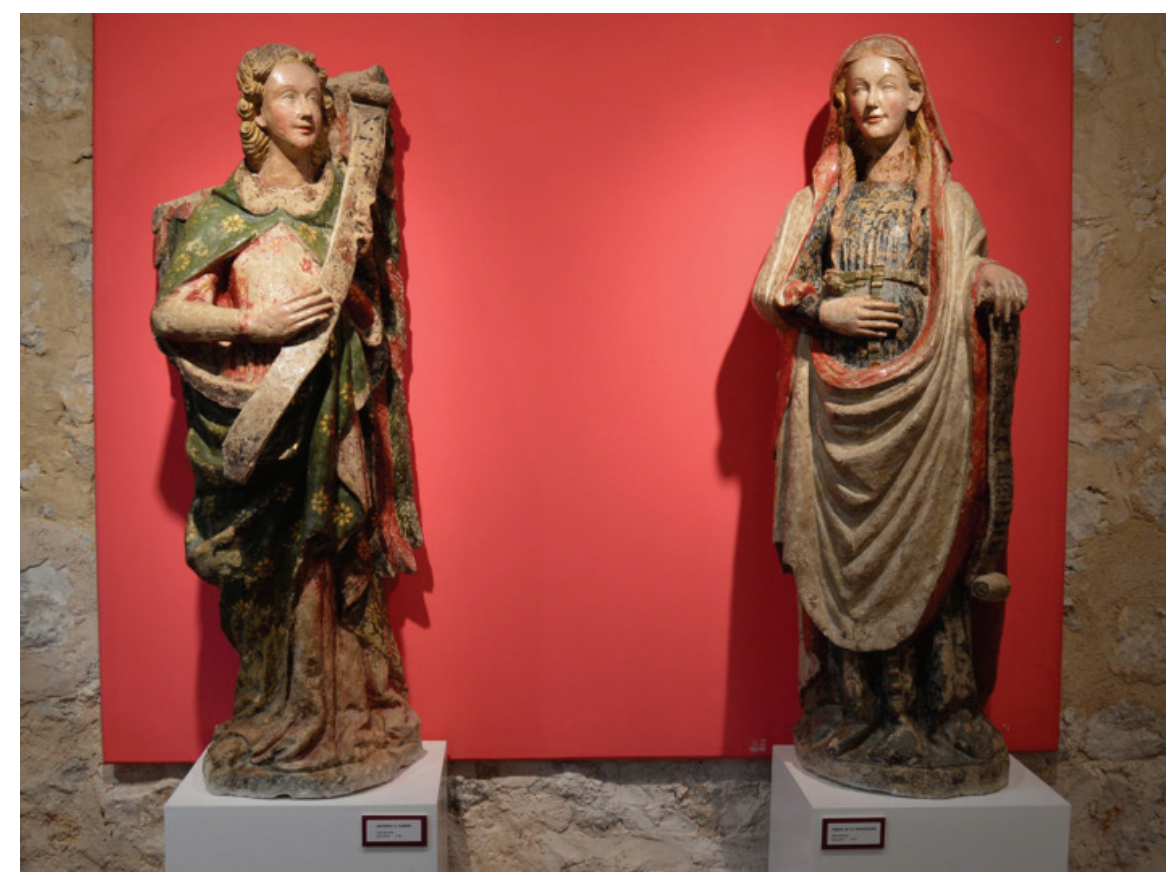

Fig. 1. Anunciación, Real Monasterio de Santo Domingo, Caleruega (Burgos), primera mitad del siglo XIV. Ubicación anterior al traslado de agosto de 2014. [Foto: autor]

retirar estas imágenes del culto, ${ }^{3}$ perdiéndose para siempre muchas de ellas, es probable que la cantidad fuese ampliamente superior. De hecho, la significativa presencia de esta tipología en los reinos peninsulares ha llevado a considerar estos grupos como una particularidad ibérica. ${ }^{4}$

manera, se hace complicado señalar una cifra concreta. Durante la realización de este trabajo hemos analizado seis grupos. Sin embargo, en MARTÍNEZ MARTÍNEZ, María José: «Las anunciaciones góticas burgalesas y los ritos hispánico y romano», Codex aquilarensis. 2012, n 28, p. 207, se habla de «veinte imágenes». La autora remite, en primer lugar, a CARDOSO ROSAS, Lúcia Maria: «Escultura y orfebrería». En: Portugal en el Medievo: de los monasterios a la monarquía, catálogo de la exposición (Madrid, 1992). Secretaría de Estado de la Cultura de Portugal, Fundación Banco Central Hispano, Consorcio para la Organización de Madrid Capital Europea de Cultura, Madrid, 1992, p. 206, que, a su vez, alude al artículo de Rocha Brito, «A gestação na escultura religiosa portuguesa: Nossa Senhora do Ó». Aunque no hemos podido consultar este último trabajo -publicado en 1945 por la revista $O$ Tripeiro-, a juzgar por su título, consideramos probable que no se reseñen únicamente ejemplares de la Anunciación.

3 TRENS, Manuel: María: iconografía de la Virgen en el arte español. Plus Ultra, Madrid, 1947, p. 75; FRANCO MATA, Ángela: Escultura gótica en León. Diputación Provincial de León, Instituto Leonés de Cultura, León, 1976, p. 392; FRANCO MATA, Ángela: Escultura gótica en León y provincia. Diputación Provincial de León, Instituto Leonés de Cultura, León, 1998, p. 362; NÚÑEZ RODRÍGUEZ, Manuel: «La Virgen de la $\mathrm{O}$ del antiguo trascoro de la catedral compostelana y su filiación conimbricense», Boletín del Seminario de Estudios de Arte y Arqueología. 1981, no 47, p. 409 y MARTÍNEZ MARTÍNEZ: 2012, op. cit., p. 207.

4 MARTÍNEZ MARTÍNEZ: 2012, op. cit., p. 206, remite a CARDOSO ROSAS: 1992, op. cit., p. 78, que realiza esta afirmación aludiendo al conjunto de imágenes de «Nuestra Señora de O», a la vez que apunta la existencia de esta iconografía en otros países de Europa, aunque en menor número. 
Con este artículo pretendemos, en primer lugar, recopilar toda la información existente sobre la Anunciación de Caleruega, ahondando en su singularidad pero incidiendo en las relaciones que mantiene con el conjunto de grupos que, como ella, enfatizan el misterio de la Encarnación en la Salutación Angélica. ${ }^{5}$ A través de esta comparación, se busca establecer unas características comunes que nos permitan aproximarnos a la reconstrucción del contexto original de las piezas de Caleruega, comprendiendo mejor el papel que pudieron ostentar dentro del cenobio y su lugar en el arte castellano del momento. ${ }^{6}$

Nos centraremos en aquellos aspectos que nos permitan adjudicarlas a una de las variantes iconográficas que creemos distinguir y que se corresponden, en líneas generales, con las realidades geográficas de Castilla, Galicia y Portugal. ${ }^{7}$ Aunque no profundizaremos en aquellos aspectos que actualmente no podemos resolver-como son los casos de la autoría y la comitencia- sí recogeremos la información disponible hasta el momento, tratando tangencialmente el monasterio fundado por Alfonso X el

5 GÓMEZ BÁRCENA, María Jesús: «La Anunciación en los sepulcros góticos burgaleses», Reales Sitios. 1983, n 78, p. 66; GÓMEZ BÁRCENA, María Jesús: Escultura gótica funeraria en Burgos. Diputación Provincial de Burgos, Burgos, 1988, p. 31; SILVA Y VERÁSTEGUI, María Soledad de: Iconografía gótica en Álava. Temas iconográficos de la escultura monumental. Diputación Foral de Álava, Vitoria, 1987, p. 71; ARA GIL, Clementina Julia: «Escultura». En: PLAZA SANTIAGO, Francisco Javier de la; MARCHÁN FIZ, Simón (dirs.): Historia del arte de Castilla y León III. Arte gótico. Plaza Universitaria, Salamanca, 1995, p. 284; MARTÍNEZ MARTÍNEZ, María José: «Imágenes góticas exentas de los siglos XIII y XIV: clasificación tipológica», Biblioteca: estudio e investigación. 2002, nº 17, p. 230 y SÁNCHEZ AMEIJEIRAS, Rocío: «Crisis, ¿qué crisis? Sobre la escultura castellana de la primera mitad del siglo XIV». En: ALCOY PEDRÓS, Rosa (ed.): El Trecento en obres. Art de Catalunya i art d'Europa al segle XIV. Universitat de Barcelona, Barcelona, 2009 , p. 250. Algunos autores inciden en que se trata de «dos temas conceptualmente distintos». NAVARRO TALEGÓN, José: «El arcángel Gabriel y la Virgen María». En: Las edades del hombre. El contrapunto y su mirada, catálogo de la exposición (Salamanca, 1993). Fundación Las Edades del Hombre, Salamanca, 1993, p. 301 .

6 Durante la realización de esta investigación hemos examinado únicamente ejemplos escultóricos. Asimismo, cronológicamente hemos acotado el estudio a la Baja Edad Media -siglos XIII-XV-, obviando la proyección posterior de la tipología. Sin embargo, lo cierto es que desconocemos la existencia de Anunciaciones de la variedad estudiada creadas con posterioridad al siglo XV en nuestro país. Sería interesante preguntarse por las razones que motivaron la decadencia de estas representaciones a finales de la Edad Media, ya que la mencionada prohibición dataría del siglo XVIII. No obstante, carecemos de datos suficientes para responder a esta cuestión, pues se trata de un aspecto que aún no ha sido trabajado. En cualquier caso, contamos con el ejemplo portugués de la Anunciación de la catedral de Évora, a cuya Virgen de la O se le añadió, ya en el siglo XVI, la figura del arcángel Gabriel, atribuida al escultor Olivier de Grand. ESPANCA, Túlio: Catedral de Évora. Folheto da Visita Guiada. Comissão Municipal de Turismo de Évora, Évora, 1946. Por otra parte, en cuanto a la delimitación geográfica, nos hemos ceñido al territorio ibérico. A día de hoy no conocemos la presencia de esta clase de Anunciaciones fuera de la Península. Sin embargo, ya que no hemos abordado el tema y que ninguno de los autores consultados desmiente su existencia, no la negaremos. Gregor Martin Lechner menciona un grupo con Virgen embarazada en el Germanisches Nationalmuseum de Nürnberg pero, al parecer, hubo una paloma sobre el vientre de María, lo cual alejaría este conjunto de la tipología ibérica. LECHNER, Gregor Martin: Maria Gravida. Zum Schwangerschaftsmotiv in der bildenden Kunst. Verlag Schnell \& Steiner München, Zürich, 1981, p. 339.

7 Entendiendo «Castilla» como la totalidad de los reinos de dicha Corona en la Baja Edad Media a excepción de los territorios gallegos. 
Sabio y escogido por el monarca como lugar de enterramiento para una de sus hijas, la infanta Leonor de Castilla y Aragón. ${ }^{8}$

\section{El estudio de las Anunciaciones Preñadas en la historiografía española ${ }^{9}$}

A día de hoy no existe un estudio que aborde el conjunto de grupos de la Anunciación en los que se representa a la Virgen en avanzado estado de gestación y tampoco se suele tratar esta particularidad en las monografías de carácter iconográfico sobre la Salutación Angélica. Esta carencia obstaculiza enormemente la tarea de los investigadores, pues se hace necesario rastrear una amplia bibliografía que, en la mayoría de las ocasiones, aporta pocos datos que, además, suelen repetir aspectos ya señalados con anterioridad. No obstante, al aumentar la variedad de los estudios que debemos consultar, multiplicamos también los puntos de vista desde los que podemos acercarnos a esta variante iconográfica.

La historiografía decimonónica no se interesó por esta clase de representaciones, ${ }^{10}$ algo que no es de extrañar si recordamos la citada recomendación eclesiástica de retirarlas del culto durante los siglos XVIII y XIX. En nuestro país, a pesar de existir menciones anteriores, ${ }^{11}$ no comenzaron a inventariarse hasta la realización del Catálogo Monumental de España, iniciado por Manuel Gómez Moreno a principios del siglo XX. Sus trabajos sobre León ${ }^{12}$ y Zamora ${ }^{13}$, en los que se recogen varios grupos, constituyen una base fundamental para los estudios posteriores. Sin embargo, la magnitud del proyecto impidió, lógicamente, profundizar en el análisis de las piezas, de

8 Alfonso X no tuvo la intención de crear un mausoleo real en Caleruega y tampoco fundó el monasterio con la idea de enterrar en él a su hija, cuyo sepulcro es una de las obras artísticas más importantes del cenobio. Recientemente ha sido restaurado con motivo de la celebración de la decimonovena muestra de Las Edades del Hombre. Los resultados del estudio pueden consultarse en la página web habilitada por la Junta de Castilla y León: http://www.jcyl.es/jcyl/patrimoniocultural/leonorf/www/index.html [última consulta: 16/02/2015].

9 Reseñamos únicamente publicaciones españolas ya que, como explicamos anteriormente en la nota 2 , durante el desarrollo de nuestra investigación nos hemos topado con la dificultad de acceder a la bibliografía portuguesa. Los fondos de las instituciones de nuestro país no cuentan con un número significativo de obras sobre el tema analizado que nos permita conocer el nivel alcanzado por los estudios lusos. Además, en la mayor parte de los casos, los ejemplares disponibles son considerablemente antiguos, lo cual nos impide calibrar la actualidad de su información. Sobre el término «Anunciación Preñada» véase el apartado 5.3.

10 CRESPO HELLÍN, Manuel: «María Grávida: la iconografía del dogma de la Encarnación de Jesucristo en María», Ars longa. 1992, n 3, p. 39.

11 A modo de ejemplo, Demetrio de los Ríos ya menciona a la Virgen del grupo de la catedral de León en su trabajo de 1895 sobre dicho edificio. ARA GIL, Clementina Julia: «Nuestra Señora la Preñada». En: Las edades del hombre: Kyrios, catálogo de la exposición (Ciudad Rodrigo, 2006). Fundación Las Edades del Hombre, Salamanca, 2006, p. 126.

12 GÓMEZ MORENO, Manuel: Catálogo monumental de la provincia de León. Ministerio de Instrucción Pública y Bellas Artes, Madrid, 1925-1926. Recoge el grupo de San Isidoro de León (p. 198) y la imagen de «la Preñada» (p. 255: lám. 318). De aquí en adelante, emplearemos la abreviatura «lám.» para referirnos a las imágenes de los trabajos consultados, independientemente de la denominación original, con el fin de homogeneizar el discurso y evitar la confusión con las imágenes del presente artículo.

13 GÓMEZ MORENO, Manuel: Catálogo monumental de la provincia de Zamora. Ministerio de Instrucción Pública y Bellas Artes, Madrid, 1927. Recoge los grupos de Santa María la Mayor de Toro (pp. 213-214; lám. 255), Santa María del Azogue de Benavente (p. 264; láms. 301 y 302) y Santa María la Real de la Hiniesta (p. 291; lám. 322). 
las que únicamente se indica ubicación y relaciones estilísticas. Resulta significativo que el investigador se limitara a catalogar indistintamente estos grupos como «Anunciación» o «Encarnación», sin señalar el evidente embarazo de María. Algo que sí hace en el caso de la Virgen de la Anunciación de la catedral leonesa, conocida como «la Preñada» y considerada por entonces como una imagen aislada.

Fueron historiadores extranjeros los primeros en vincular esta obra con el pasaje de la Anunciación. Ya en 1925, al mismo tiempo que Gómez Moreno publicaba su primer catálogo, el alemán Georg Weise, en sus estudios sobre la escultura española, apuntaba la posible pertenencia de la Preñada de León y otras imágenes de la Virgen a grupos de la Salutación Angélica. ${ }^{14}$ Pocos años después, en la década de los treinta, otro alemán, Hannshubert Mahn, repetía la operación en uno de los apéndices de su trabajo sobre las catedrales de Castilla, León y Navarra. ${ }^{15}$ Según este autor, la obra podría haber formado una Anunciación junto con otra imagen, también aislada, del arcángel Gabriel, conocida como "Ángel de Reims» ${ }^{16}$ y ubicada actualmente a la izquierda de la Portada de la Virgen del Dado. Su deducción se basó en las evidentes similitudes de ambas esculturas con el grupo de la colegiata de San Isidoro, situada en la misma ciudad, que supuestamente sería una copia del catedralicio. ${ }^{17}$

Sin embargo, al igual que Gómez Moreno, ninguno de estos dos investigadores hizo alusión a la gravidez de María, siendo el estadounidense Frederick B. Deknatel el primero en llamar la atención sobre ello. En su exhaustivo estudio sobre las catedrales de Burgos y León, además de retomar la hipótesis de Mahn, el americano se refiere a la Preñada ya como Virgin of the Annunciation ${ }^{18}$ y reconoce la existencia de toda una serie de grupos que habrían derivado del leonés. ${ }^{19}$ Esto es interesante porque, como indicaremos más adelante, desde que Ángela Franco Mata estudiase esta pareja de esculturas (Fig. 2) casi cuarenta años después, está considerada como la Anunciación más antigua de esta variante y, por tanto, el origen de la misma.

14 WEISE, Georg: Spanische Plastik aus Sieben Jahrhunderten. Vol. 1. Gryphius, Reutlingen, 1925, p. 24. Junto a otros grupos de la Anunciación, menciona los inventariados por Gómez Moreno -Toro (láms. 46 y 47), Benavente (láms. 48 y 49), San Isidoro de León, la Preñada de León (lám. 50)- y la Virgen embarazada de la iglesia de Santiago de Medina del Campo (lám. 51).

15 MAHN, Hannshubert: Kathedralplastik in Spanien. Die Monumentale Figuralskultur in Kastilien, León und Navarra. Zwischen 1230 und 1380. Gryphius, Reutlingen, 1931, pp. 61-63. A los grupos inventariados por Gómez Moreno en León y Zamora -San Isidoro de León (láms. 210 y 211), Toro (láms. 214 y 215), Benavente (láms. 218 y 219), La Hiniesta (láms. 216 y 217)- añade el sepulcro del arcediano Díaz de Peñafiel en la catedral de Burgos (láms. 206 y 207), citándolo únicamente como «kleinen Beispiel am Grabmal eines 1333 gestorbenen Geistlichen» (traducción libre: «pequeño ejemplo en el sepulcro de un clérigo fallecido en 1333»), la Catedral Vieja de Vitoria (láms. 220 y 221), la catedral de Tarazona (láms. 222 y 223) y el Hospital de Esgueva de Valladolid (láms. 226 y 227), que todavía no había sido derribado.

16 Mahn no empleó este nombre. Simplemente identifica el arcángel como la escultura que se encontraba en la capilla de San Andrés. Fue Deknatel quien, más adelante, relacionó la escultura de León con el Gabriel de la catedral de Reims y la denominación aparece por primera vez en FRANCO MATA: 1976, op. cit.

17 MAHN: 1931, op. cit., p. 62.

18 DEKNATEL, Frederick B.: «The Thirteenth Century Gothic Sculpture of the Cathedrals of Burgos and Leon», The Art Bulletin. 1935, nº 17, p. 383 y lám. 95.

19 DEKNATEL: 1935, op. cit., p. 384. Sus palabras exactas son: «series of Annunciations in which the Virgin is pregnant which are without question derived from the separated Leon sculptures». Utiliza como ejemplos Toro (láms. 98 y 99), Benavente, La Hiniesta (láms. 96 y 97), Vitoria, Tarazona (láms. 100 y 101) y San Isidoro de León. 

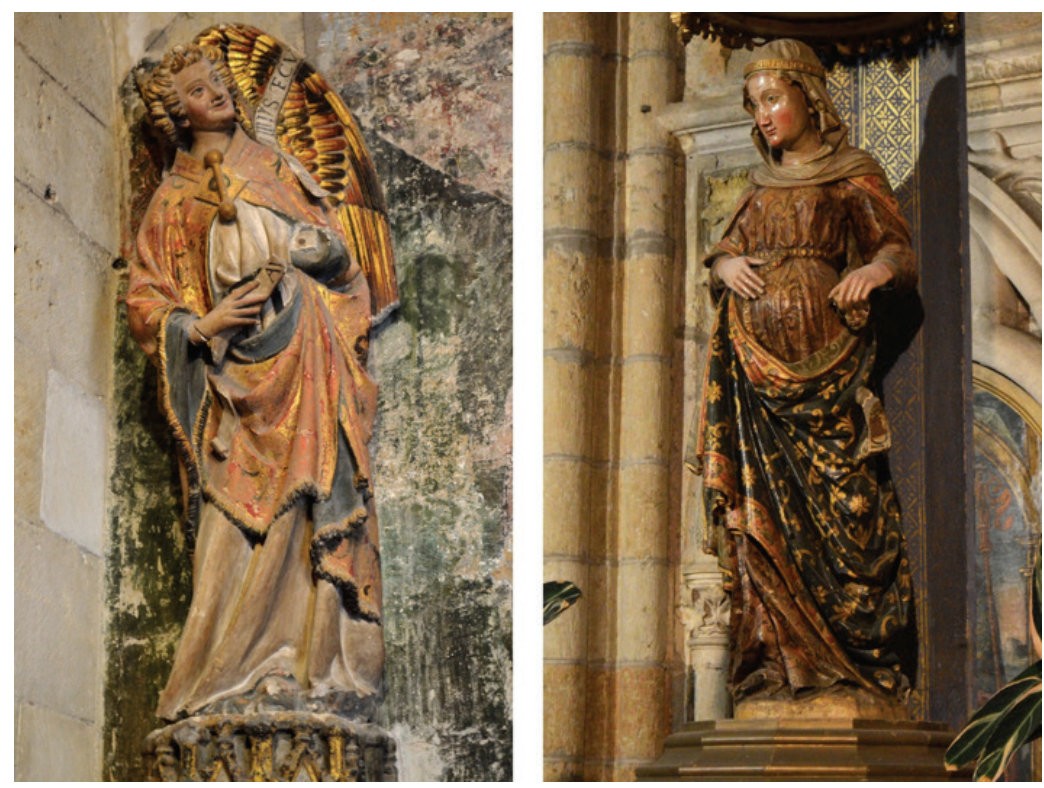

Fig. 2. Anunciación (Ángel de Reims y Nuestra Señora la Preñada), Catedral de Santa María de Regla, León (León), segunda mitad del siglo XIII. [Fotos: autor]

A mediados del siglo XX, comenzamos a encontrar breves menciones de estas piezas en estudios iconográficos de carácter general. En la obra de referencia de Manuel Trens sobre iconografía mariana aparece de nuevo la Preñada de León. Al no contar con un apartado específico para los relatos bíblicos, la imagen se incluye dentro del epígrafe de la Virgen de la Esperanza o de la O, sirviendo al autor para diferenciar a las Vírgenes embarazadas aisladas de aquellas que formaron parte de una Anunciación. ${ }^{20}$

Louis Réau escogió la misma obra para su apartado sobre La Vierge encinte de l'Expectation. ${ }^{21}$ Sin embargo, el iconógrafo francés no informa de su pertenencia a un grupo de la Salutación Angélica. Únicamente relaciona estas imágenes con la institución de la fiesta de la Expectación de la Virgen el 18 de diciembre, señalando la importancia que adquirió el tema en los actuales territorios de España y Portugal. ${ }^{22}$ Además, indica que el momento de su apogeo tuvo lugar al final de la Edad Media, afirmación que ha sido desmentida por la cronología de los grupos contabilizados. ${ }^{23}$

Conforme los estudios iconográficos se fueron tornando más específicos, se demostró que el motivo del embarazo en la Anunciación no fue algo exclusivo de la

\footnotetext{
20 TRENS: 1947, op. cit., p. 84.

21 RÉAU, Louis: Iconographie de l'art chrétien II. Iconographie de la Bible, 2, Nouveau Testament. Presses Universitaires de France, Paris, 1957, pp. 90-91.

22 Como muestra incluye la mencionada Virgen Preñada de Medina del Campo que, como ya sopesó Weise y más tarde apuntó Ara Gil (ver nota 123), hoy se considera que pudo formar parte de una Anunciación.

23 FRANCO MATA: 1976, op. cit., p. 393 y en su reedición FRANCO MATA: 1998, op. cit., p. 360.
} 
escultura monumental. En sus trabajos sobre la temática de los ámbitos funerarios, María Jesús Gómez Bárcena constató la importancia que tuvo este pasaje evangélico en los sepulcros góticos por considerarse un preludio de la Redención. ${ }^{24}$ En el caso concreto de Burgos, recogió varias esculturas en las que la Virgen apoya su mano derecha sobre el vientre, llevando a la autora a sopesar que con ello se pretendiese «asociar el tema de la Anunciación con el de la Encarnación ${ }^{25}$. A la misma conclusión llegó María Soledad de Silva y Verástegui en su estudio sobre las representaciones iconográficas de la provincia de Álava, donde señaló gestos similares en los tímpanos de varias portadas. ${ }^{26}$

Por las mismas fechas, el alemán Gregor Martin Lechner había publicado ya la que está considerada como la obra fundamental para las investigaciones sobre la representación del embarazo de la Virgen: Maria Gravida. Zum Schwangerschaftsmotiv in der bildenden Kunst. En este libro, que supone un completo recorrido por el arte universal desde el anuncio de Gabriel hasta el Nacimiento de Cristo, encontramos ya un apartado específico para la Anunciación. ${ }^{27}$ Sin embargo, el hecho de que se trate de una investigación centrada en la figura de María, conlleva que se preste escasa atención al arcángel. Además, el breve espacio que ocupa el epígrafe -apenas dos páginas frente a las, por ejemplo, veinticinco dedicadas a la Madonna del Parto- se comparte con las Anunciaciones con Niño y las Vírgenes encinta aisladas, lo cual limita el uso de este trabajo para el estudio de la tipología que estamos tratando.

No obstante, además de aportar interesantes reflexiones acerca del significado del embarazo, Lechner recoge una serie de grupos gallegos y portugueses que nos permite conocer las otras variantes de la Anunciación Preñada en la península ibérica. ${ }^{28}$ Lo mismo ocurre con la publicación relativamente reciente de Manuel Crespo Hellín. ${ }^{29}$ En esta ocasión, por fin se incluye un apartado exclusivo para la tipología que nos ocupa aunque, de nuevo, es muy breve y no incluye esculturas castellanas. En cualquier caso, retoma dos de los ejemplos propuestos por Lechner: la Virgen de la O de San Pedro de Balsemão en Lamego ${ }^{30}$ y la Anunciación de la catedral de Santiago de

24 GÓMEZ BÁRCENA: 1983, op. cit., p. 65 y GÓMEZ BÁRCENA: 1988, op. cit., p. 31.

25 GÓMEZ BÁRCENA: 1983, op. cit., p. 66. La reflexión deriva del gesto de María en el sepulcro del obispo Lope de Fontecha (láms. 1, 2 y 3, p. 67). Sin embargo, no se señala en el de Díaz de Peñafiel (láms. 4 y 6, p. 67), que consideramos más evidente. Esta situación se repite en estudios posteriores en los que la autora vuelve a trabajar ambos sepulcros: GÓMEZ BÁRCENA: 1988, op. cit. Aunque no lo menciona en el apartado dedicado a Lope de Fontecha (pp. 67-69), sí lo indica al referirse al episodio de la Anunciación (p. 31). Nuevamente, no se apunta esta característica en el sepulcro de Díaz de Peñafiel (pp. 100-101).

26 SILVA Y VERÁSTEGUI: 1987, op. cit. Recoge los grupos del pórtico de la Catedral Vieja de Vitoria (pp. 69-72) y los tímpanos de la misma (p. 67; lám. p. 66) y de Santa María de los Reyes de Laguardia (p. 69; lám. p. 68).

27 LECHNER: 1981, op. cit., pp. 85-86.

28 LECHNER: 1981, op. cit. Recoge los grupos de la iglesia de Santa María Salomé de Santiago de Compostela (p. 337), la catedral de la misma ciudad (p. 337; lám. 6), la catedral de Évora (p. 337), la Capela do Fundador de dicho edificio (p. 340) y la catedral de Tui (p. 339). Considera que la Preñada de León es una figura aislada del siglo XVI (p. 430).

29 CRESPO HELLÍN: 1992, op. cit.

30 CRESPO HELLÍN: 1992, op. cit., p. 41. El discurso puede resultar confuso, pues el autor indica que la localidad es «Malsemäo» cuando Lechner, de quien toma la referencia, habla de «Balsemão»: LECHNER: 
Compostela ${ }^{31}$, grupo que identificamos como prototipo de la variante gallega. Precisamente en el año en que veía la luz el trabajo de Lechner, Manuel Núñez Rodríguez daba a conocer desde Galicia su estudio monográfico sobre este último grupo, que relaciona con el ámbito portugués y especialmente con la ciudad de Coimbra. ${ }^{32}$

Sobre estas relaciones artísticas de mutua influencia iconográfica profundizó más adelante María Dolores Barral Rivadulla. ${ }^{33} \mathrm{Su}$ discurso trasversal fue posible gracias al trabajo previo, de carácter enciclopédico, realizado por Carmen Manso Porto, que recopiló la mayoría de los ejemplos gallegos que conocemos, ${ }^{34}$ destacando la relevancia del grupo de la catedral compostelana y su reflejo en la portada de la cercana iglesia de Santa María Salomé, también en la capital gallega.

Paralelamente a estos estudios, las Anunciaciones castellanas fueron tratadas en publicaciones relativas a la escultura de diferentes provincias. En ellas, los autores se dedicaron a ejemplos concretos, estableciendo relaciones con aquellos que consideraron más similares, pero sin llegar a realizar una visión de conjunto. Dentro de este panorama, debemos destacar nuevamente los trabajos sobre el grupo de la catedral de León. Fue estudiado por Franco Mata en su tesis doctoral sobre la escultura leonesa, dirigida por José María Azcárate Ristori, que defendió en 1974 y publicó dos años después. ${ }^{35}$ En ella retomó la hipótesis de Weise, Mahn y Deknatel, considerando que la Preñada habría representado la Anunciación junto con el llamado "Ángel de Reims». Años más tarde, en la revisión del libro, ya señalaba convencida esta afirmación. ${ }^{36} \mathrm{~A}$ pesar de todo, en estudios posteriores, investigadores como Clementina

1981, op. cit., p. 339. Desconocemos si el ejemplo portugués cuenta con arcángel pero, en cualquier caso, la Virgen sigue el prototipo de las Anunciaciones lusas.

31 CRESPO HELLÍN: 1992, op. cit., p. 41. Nuevamente, la referencia es errada, ya que fecha el grupo en el siglo XVI cuando, en realidad, el libro citado lo sitúa en el siglo XV que, como explicaremos en la nota 107, es una de las dos cronologías que se barajan para esta obra: CHAMOSO LAMAS, Manuel: La catedral de Santiago de Compostela. Everest, León, 1981, p. 91.

32 NUUNEZZ RODRÍGUEZ: 1981, op. cit. Concretamente menciona el arcángel de la Anunciación de San Juan de Tarouca (p. 413; lám. 2) -que no hemos podido vincular a ninguna imagen de María-, y de tres Vírgenes de la $\mathrm{O}$, dos en el Museo de Lamego (p. 414; láms. 1 y 3 ) y una en Vila do Castelo (lám. 4).

33 BARRAL RIVADULLA, María Dolores: «Encrucijadas en la escultura gótica: el ámbito galaico-portugués», Boletín del Museo e Instituto Camón Aznar. 2007, $\mathrm{n}^{\circ}$ 100. Recoge los grupos de San Martín de Noia (p. 16), la catedral de Tui (p. 17), la portada de San Francisco de Betanzos (p. 17; lám. 4), Santa María del Azogue de Betanzos (p. 17) y la catedral de Santiago de Compostela (lám. 5). También menciona el grupo que «adorna el arcosolio de un caballero del linaje de los Maldonado en Santo Domingo de Rivadavia (Ourense)» pero no lo incluimos en el presente estudio al no haber podido comprobar su iconografía.

34 MANSO PORTO, Carmen; YZQUIERDO PERRÍN, Ramón: «El arte gótico». En: Arte Medieval II. Galicia, Arte. T. XI. Hércules, A Coruña, 1996. Además de las Anunciaciones que aprovecha Barral Rivadulla-Noia (p. 352; lám. p. 437), Tui (láms. p. 434), catedral de Santiago de Compostela (lám. p. 435), portada de San Francisco de Betanzos (lám. p. 346 y lám. p. 437)-, Manso Porto también incluyó la de Santa María de Gracia en el castillo de Monterrei (lám. p. 377 y lám. p. 435). En el caso de Santa María del Azogue de Betanzos (pp. 304 y 342; láms. p. 340) no señala que su virgen esté embarazada.

35 FRANCO MATA: 1976, op. cit. Además de relacionar el grupo con la Anunciación de San Isidoro, también lo hace con las de Benavente, La Hiniesta, Toro, Vitoria y Tarazona. Así como con la Virgen de Medina del Campo, que la autora aún no había alcanzado a ver.

36 FRANCO MATA: 1998, op. cit. A los grupos con los que ya había relacionado la Anunciación (láms. 220 y 221) en la primera versión -San Isidoro (lám. 222), Toro (láms. 223 y 224), La Hiniesta, Benavente (láms. 225 y 226), Vitoria (láms. 227 y 228) y Tarazona (lám. 229)- añade el ángel de Sasamón y, tras la publicación de ARA GIL, Clementina Julia: Escultura gótica en Valladolid y su provincia. Instituto Cultural de 
Julia Ara Gil, continúan señalando que se trata de una imagen aislada. ${ }^{37}$ Precisamente con un criterio geográfico, esta autora trabajó la escultura gótica de la provincia de Valladolid, recogiendo nuevos grupos. ${ }^{38}$

Hubo que esperar a los artículos de María José Martínez Martínez para que la Anunciación de Caleruega se incluyese en esta clase de estudios. A esta autora corresponden los primeros trabajos que tratan de relacionar el grupo con el resto de la tipología, centrándose en el ámbito burgalés y en la convivencia de las dos maneras de representar el pasaje evangélico en la Baja Edad Media, es decir, con y sin embarazo. Tras un primer acercamiento en el que ya relacionó la variante que estudiamos con la liturgia hispana, ${ }^{39}$ llegó a incluir las esculturas caleroganas en trabajos de carácter general sobre la escultura de Burgos, ${ }^{40} \mathrm{y}$ diez años más tarde, la autora volvió a profundizar sobre el tema con un estudio más exhaustivo. ${ }^{41}$

En los últimos años, Rocío Sánchez Ameijeiras se ha preguntado por el origen de este tipo de imágenes. Las ha relacionado con una posible utilización política por parte de la reina María de Molina y su entorno, ${ }^{42}$ así como con la intención de catequizar a las comunidades judías. ${ }^{43}$ En cualquier caso, la autora, que también ha

Simancas, Diputación Provincial de Valladolid, Valladolid, 1977, señala también «ecos más lejanos» en los grupos del hospital de Esgueva de Valladolid, actualmente en los depósitos del Museo Nacional de Escultura, y el procedente de Castronuño que se conserva en el Museo Diocesano y Catedralicio de la misma ciudad.

37 ARA GIL: 1995, op. cit., p. 284. Además, señala la Virgen Preñada de Medina del Campo como escultura aislada y pone como ejemplo de grupos las Anunciaciones de Toro, Benavente, La Hiniesta e, incluso, la catedral de Palencia, que no consideramos parte de esta tipología al no apoyar la Virgen su mano sobre el vientre. Recoge la polémica entre Franco Mata y Ara Gil: MARTÍNEZ MARTÍNEZ, María José: 2002, op. cit., p. 230, nota 202.

38 ARA GIL: 1977, op. cit. Recoge el mencionado grupo del hospital de Esgueva (pp. 192-194; lám. LXXVII) y el del Museo Diocesano y Catedralicio (p. 171; lám. LXVII, 1).

39 MARTÍNEZ MARTÍNEZ: 2002, op. cit., pp. 230-231. Señala como figuras aisladas la Preñada de León y la de Medina del Campo. Como grupos de la Anunciación recoge las de Benavente, Toro, la Hiniesta, Palencia (ver nota 37), Museo Diocesano y Catedralicio de Valladolid, San Isidoro de León, Tarazona, Caleruega (láms. p. 229) y el ángel de Sasamón. Sobre este último, figura aislada, no estamos seguros, al igual que la autora, de su pertenencia a un grupo de la Anunciación al no tener documentación que así lo detalle. No obstante, y aunque no lo incluimos en el presente trabajo, consideramos que la presencia de la Anunciación Preñada de la fachada sur (ver nota 108) hace que esta posibilidad no sea del todo descartable.

40 MARTÍNEZ MARTÍNEZ, María José: «La imaginería gótica burgalesa: más allá de la devoción». En: RODRÍGUEZ PAJARES, Emilio Jesús; BRINGAS LOPEZ, María Isabel (coords.): El arte gótico en el territorio burgalés. Universidad Popular para la Educación y Cultura de Burgos, Burgos, 2006, p. 262.

41 MARTÍNEZ MARTÍNEZ: 2012, op. cit., p. 207. Recoge hasta el momento la lista más completa de Anunciaciones Preñadas de la variedad castellana, señalando las ya conocidas de la catedral de León, San Isidoro de León, Medina del Campo -aunque en la nota 25 indica que la escultura está aislada-, La Hiniesta, Toro, Museo Diocesano y Catedralicio de Valladolid, Vitoria y Tarazona. Además, añade la del Museo del Greco en Toledo y hace una breve mención a la de la catedral de Santiago de Compostela y a la presencia de grupos en Portugal. Caleruega (láms. 4 y 5). Sobre el Ángel de Sasamón (pp. 215-216; láms. 6 y 7), ver nota 39.

42 SÁNCHEZ AMEIJEIRAS, Rocío: «Cultura visual en tiempos de María de Molina: poder, devoción y doctrina». En: SEVILLANO SAN JOSÉ, María Carmen (coord.): El conocimiento del pasado: una herramienta para la igualdad. Plaza Universitaria, Salamanca, 2005, p. 316. Vincula la creación de los grupos de La Hiniesta (lams. 17 y 18), Toro y Benavente con el renovado auge de la fiesta de la Expectación y la creación de «alter-egos de la reina madre María».

43 SÁNCHEZ AMEIJEIRAS: 2009, op. cit., pp. 250-256. Incluye los grupos de la catedral de León (p. 250 y 251), Toro (p. 251; láms. 2a y 2b), La Hiniesta (p. 251) y Benavente (p. 251). 
incluido estos grupos en estudios de género, ${ }^{44} \mathrm{y}$ que no considera excluyentes ambas interpretaciones, ${ }^{45}$ apuesta por situar el origen de esta iconografía en los territorios de León y Zamora. ${ }^{46}$

Por otra parte, el desarrollo cultural experimentado por nuestro país en las últimas décadas ha permitido la dinamización de los estudios y la apuesta por proyectos más ambiciosos. En este sentido, las labores de restauración del patrimonio han jugado un papel fundamental, siendo especialmente relevantes los planes directores de las catedrales. Ejemplos como el de la Fundación Catedral Santa María de Vitoria o el Proyecto Cultural Catedral de León conllevan la renovación integral de las investigaciones sobre sus respectivos edificios, generando una gran cantidad de documentación en la que podemos encontrar datos actualizados sobre los grupos de la Anunciación que nos ocupan. ${ }^{47}$

Lo mismo ocurre en el caso de los museos, con la edición de nuevos catálogos, ${ }^{48} \mathrm{o}$ en el de los trabajos monográficos sobre edificios concretos. ${ }^{49}$ Por último, y también dentro de este ámbito, la aparición de Las Edades del Hombre ha supuesto una vía más para dar a conocer estas Anunciaciones que, en su mayoría, se conservan en la comunidad de Castilla y León.

\section{Historia de la obra: cronología y ubicaciones conocidas}

Fue precisamente durante una de las exposiciones de Las Edades del Hombre, concretamente en la inaugurada en mayo de 2009 en la concatedral de Soria, cuando se produjo la primera salida que tenemos documentada de la Anunciación de Caleruega fuera del monasterio. Hasta entonces, las obras habían resultado prácticamente desconocidas y aún hoy contamos con pocos datos fidedignos acerca de su origen. Si bien existen varias hipótesis sobre su cronología, se ignora su emplazamiento inicial

\footnotetext{
44 SÁNCHEZ AMEIJEIRAS, Rocío: «De la cabeza al corazón: cuerpos femeninos, arte contemporáneo e historia de la cultura medieval», Sémata: Ciencias Sociais e Humanidades. 2008, nº 20, p. 321.

45 SÁNCHEZ AMEIJEIRAS: 2008, op. cit., p. 247, nota 16.

46 SÁNCHEZ AMEIJEIRAS: 2005, op. cit., p. 316 y SÁNCHEZ AMEIJEIRAS: 2008, op. cit., p. 251.

47 En el caso de la Catedral Vieja de Vitoria, el plan director incluye un estudio sobre la Anunciación de su pórtico: LAHOZ GUTIÉRREZ, Lucía: «Sugerencias sobre la imagen de Santa María de Vitoria-Gasteiz». En VV. AA.: Catedral de Santa María. Vitoria-Gasteiz. Plan Director de Restauración. Fundación Catedral Santa María, Diputación Foral de Álava, Vitoria, 2002, p. 221. Por su parte, la catedral de León ha optado por publicar una versión actualizada de la guía escrita a mediados del siglo XX por el canónigo archivero, que cuenta con una breve ficha sobre su Anunciación: RODRÍGUEZ VEGA, Raimundo: Pulchra Leonina. Guía para visitar la Catedral de León, 1947 [Edición de RODRÍGUEZ MONTAÑÉS, José Manuel. Cabildo de la S. I. Catedral de León, León, 2013, pp. 146-147].

48 En el catálogo del museo de la catedral de Santiago de Compostela se incluye una ficha breve pero acertada del grupo conservado en su colección: YZQUIERDO PEIRÓ, Ramón: Museo Catedral de Santiago. Cabildo de la Catedral, Consorcio de Santiago, Santiago de Compostela, 2011, pp. 74-75.

49 Tal es el caso del libro patrocinado por el Centro de Estudios Benaventanos sobre la iglesia de Santa María del Azogue de Benavente: HIDALGO MUÑOZ, Elena: La iglesia de Santa María del Azogue de Benavente. Centro de Estudios Benaventanos «Ledo del Pozo», Benavente (Zamora), 1995, pp. 55-56.
} 
y, aunque en algún caso se ha señalado la posibilidad de una autoría foránea ${ }^{50}$ la mayoría de los estudios coinciden en mantener el anonimato de las piezas. ${ }^{51}$

Durante años, la memoria colectiva de la comunidad ha mantenido la tradición de que el grupo procedía del monasterio femenino de Santa María de Castro en San Esteban de Gormaz, primitivo emplazamiento de la congregación antes de su traslado a Caleruega. ${ }^{52}$ Sin embargo, actualmente se piensa que fueron creadas para la iglesia del nuevo edificio de la villa burgalesa, ${ }^{53}$ del que las monjas tomaron posesión el 11 de julio de 1270 , cuatro años después del comienzo de las obras. ${ }^{54}$ Dejando al margen la supuesta procedencia sanestebeña, los diferentes estudios fechan el conjunto entre los siglos XIII y XIV, siendo la tendencia general la de retrasar su cronología progresivamente. ${ }^{55}$ De hecho, las últimas hipótesis sitúan su realización hacia los años cuarenta del siglo XIV, ${ }^{56}$ durante el reinado de Alfonso XI, biznieto del rey Sabio.

Tanto la iglesia como el monasterio ostentaban por entonces la titularidad de Santa María - concretamente de la Anunciata, en el caso de la iglesia, según Martínez Martínez- $-^{57}$ en lugar de encontrarse bajo la advocación de Santo Domingo. ${ }^{58}$ De esta

50 PEREDA SAINZ, Elsa: Anunciación. Real Monasterio de Santo Domingo de Guzmán. Caleruega. Memoria de restauración inédita. Servicio Territorial de cultura de Burgos, 2009, p. 7. Citando a la comunidad, explica que en Alemania existe otra obra inaugurada en la misma época que «por su estilo y factura es obra del mismo autor». No obstante, actualmente las dominicas manifiestan desconocer dicha imagen.

51 La propia cartela situada junto a las imágenes señala el anonimato. Si bien todos los autores secundan este dato al no mencionar un autor concreto, lo hacen explícitamente: PEREDA SAINZ: 2009, op. cit., p. 7 y ZAPARAÍN YÁÑEZ, María José: «Anunciación de la Virgen». En: Las Edades del Hombre: Paisaje interior, catálogo de la exposición (Soria, 2008). Fundación Las Edades del Hombre, Valladolid, 2009, p. 507.

52 Así quedó recogido en el folleto de la exposición «Santo Domingo de Guzmán. Palabra e Imagen», celebrada en 2001 en el propio monasterio. También se indica esta teoría en PEREDA SAINZ: 2009, op. cit., p. 7. Pero es en la página web de la Orden de Predicadores donde se especifica la fecha del traslado del grupo: http:// www.dominicos.org/santo-domingo/lugares/caleruega [última consulta: 16/02/2015]. Para más información sobre la comunidad de San Esteban de Gormaz: GONZÁLEZ GONZÁLEZ, Carmen: Real Monasterio de Santo Domingo de Caleruega. Fundación de Alfonso X El Sabio. San Esteban, Salamanca, 1993, pp. 21-56 y RÍOS DE LA LLAVE, Rita: Mujeres de clausura en la Castilla Medieval: El Monasterio de Santo Domingo de Caleruega. Universidad de Alcalá, Alcalá de Henares, 2007, pp. 55-128.

53 PEREDA SAINZ: 2009, op. cit., p. 7; ZAPARAÍN YÁÑEZ: 2009, op. cit., p. 507 y MARTÍNEZ MARTÍNEZ: 2012, op. cit., p. 214.

54 GONZÁLEZ GONZÁLEZ: 1993, op. cit., pp. 71-72 y RÍOS DE LA LLAVE: 2007, op. cit., pp. 149150 .

55 La cartela que acompaña las imágenes las fecha en el siglo XIII, al igual que VV.AA.: Santo Domingo de Guzmán. Palabra e Imagen, catálogo de la exposición (Caleruega, 2001). Castuera, Torrez de Elorz (Navarra), 2001, p. 27; MARTÍN LOZANO, José Enrique; VICENTE PRADAS, José María: Real Monasterio de Caleruega: Cuna de Santo Domingo de Guzmán. Edilesa, Trobajo del Camino (León), 2007, p. 49 y PEREDA SAINZ: 2009, op. cit., p. 7. Años antes, GONZÁLEZ GONZÁLEZ: 1993, op. cit., aun fechando el grupo en el siglo XIII (p. 103), lo incluyó dentro del epígrafe sobre las obras llevadas a cabo durante el reinado de Sancho IV (p. 99), retrotrayéndolas a finales de la centuria. Algo que también hace ZAPARAÍN YÁÑEZ: 2009, op. cit., p. 507, que además presenta la posibilidad de que fueran realizadas a principios del siglo XIV.

56 MARTÍNEZ MARTÍNEZ: 2012, op. cit., p. 215. La autora llega a esta conclusión basándose en la indumentaria con la que fueron representados los personajes y en la buena situación económica que disfrutaba el monasterio en ese momento.

57 MARTÍNEZ MARTÍNEZ: 2012, op. cit., p. 214. Agradece esta información a Sor Carmen González González, quien no la incluye en su libro sobre el monasterio publicado diecinueve años atrás.

58 GONZÁLEZ GONZÁLEZ: 1993, op. cit., p. 103. Apunta que la titularidad de la iglesia monástica «siempre fue de Santa María, hasta que dejó de ser iglesia para convertirse en simple coro de las monjas». 
manera, se evitaba duplicar esta última, de cuya protección ya disfrutaba la iglesia levantada por el hermano del santo, el beato Manés. Según Sor Carmen González González -antigua archivera del monasterio a quien debemos la primera referencia conocida de la Anunciación- ${ }^{59}$, las esculturas «presidían el altar mayor» ${ }^{60}$, mientras que María José Zaparaín Yáñez opina que pudieron encontrarse «en los pilares torales» ${ }^{61}$ del templo, como ocurre con grupos similares en otras iglesias.

La importancia del tema no hace extraña su ubicación privilegiada dentro del edificio. De hecho, está documentada la presencia de otra Anunciación en el coro del desaparecido monasterio de Santo Domingo de Madrid - una de las tres únicas comunidades de dominicas en el reino Castilla durante buena parte de la Edad Media junto con las de Caleruega y Zamora-. ${ }^{62}$ Aunque no hay indicios de que la Virgen de este conjunto se representara en avanzado estado de gestación y desconocemos si se trataba de una obra escultórica y medieval, lo cierto es que constituyó «una de las estaciones en el canto de la Calenda que daba inicio a la Navidad», ${ }^{63}$ con lo que se encontraría en sintonía con la fiesta de la Expectación que, como veremos más adelante, está íntimamente ligada a la tipología que estudiamos.

El hecho de que el grupo de Caleruega se encuentre actualmente en el museo del monasterio ha llevado a pensar que pudo haber sido trasladado en el momento en que se mandó retirar esta clase de imágenes del culto. ${ }^{64}$ No obstante, parece que el cambio se produjo por motivos diferentes. Desde las reformas acometidas en el siglo XVIII, no se habían realizado obras de mejora en el monasterio que, a principios del siglo XX, presentaba un evidente deterioro. Esta situación hizo que la Orden sintiera la necesidad de dignificar el lugar, con lo que, en el Capítulo de 1913, se propuso la construcción de una gran basílica - nunca edificada- y otras intervenciones. El proyecto no fue aprobado hasta 1930, momento en que se inició el contacto con los hermanos Menéndez Pidal, cuyos planos de la situación previa del monasterio, fechados en 1949, constituyen una fuente imprescindible para el estudio del edificio.

En 1952 se inició la construcción del convento de dominicos en terrenos cedidos por las monjas. Sus obras debieron de acaparar la totalidad de los fondos, pues hasta

59 La incluyó, sin señalar el embarazo de la Virgen, en el libro que realizó durante su labor como archivera. GONZÁLEZ GONZÁLEZ: 1993, op. cit., p. 99; lám. p. 139. El privilegiado acceso de la autora a la documentación del monasterio convierte esta publicación en una obra clave para los estudios sobre el mismo. Hasta entonces, el grupo había resultado prácticamente desconocido. No aparece mencionado en el Catálogo monumental de la provincia de Burgos, realizado por Narciso Sentenach Cabañas entre 1922 y 1924 , que dedica tres páginas a Caleruega.

60 GONZẢLEZ GONZÁLEZ: 1993, op. cit., p. 99. De esta opinión se hace eco MARTÍNEZ MARTÍNEZ: 2012, op. cit., p. 214.

61 ZAPARAÍN YÁÑEZ: 2009, op. cit., p. 508.

62 RÍOS DE LA LLAVE: 2007, op. cit. pp. 54 y 407.

63 PÉREZ VIDAL, Mercedes: «Quinze imágenes de nuestra señora. Arte y devoción mariana en el monasterio de Santo Domingo el Real de Madrid». En: CAMPOS Y FERNÁNDEZ DE SEVILLA, Francisco Javier (coord.): La clausura femenina en el Mundo Hispánico: una fidelidad secular. Vol. 2. Ediciones Escurialenses, San Lorenzo de El Escorial, 2011, p. 932. Además de la Anunciación del coro se habla de otras dos «imágenes» del mismo pasaje que coronaban los retablos de la segunda y de la tercera capilla del lado de la Epístola, dedicadas respectivamente a la Sagrada Familia y a la Adoración de los Reyes Magos. La autora no precisa ni la cronología ni el formato de estas Anunciaciones.

64 MARTÍNEZ MARTÍNEZ: 2012, op. cit., p. 207. 
la providencial ayuda de Pedro Masaveu no se pudieron acometer las reformas necesarias en el monasterio femenino - llevadas a cabo entre 1958 y $1959-.{ }^{65}$ Los trabajos afectaron especialmente al coro de monjas, situado en la antigua iglesia de Alfonso $\mathrm{X}$, donde se eliminó el tabique en el que se ubicaba el acceso a las dependencias monacales para levantar uno más cercano. Aquí se encontraba por entonces el grupo de la Anunciación, fuera del coro propiamente dicho y sobre un pequeño altar a la derecha del vano, mientras que, a la izquierda, estaba situada una imagen de Santo Domingo que podemos intuir en una de las secciones realizadas por Menéndez Pidal (Fig. 3) y que, a día de hoy, también se encuentra en el museo del cenobio. ${ }^{66}$

La reforma obligó a trasladar las esculturas y estas pasaron a custodiarse en la antigua sala capitular, convertida en zaguán del claustro. Allí permanecieron hasta que, aprovechando las reformas de este espacio, que tuvieron lugar entre 1968 y 1975, se reubicaron en la sala contigua, donde se encuentran actualmente y que solo han abandonado con motivo de las dos exposiciones en las que ha participado hasta la fecha: ${ }^{67}$ «Santo Domingo de Guzmán. Palabra e Imagen», organizada en 2001 en el mismo monasterio y la mencionada de «Las Edades del Hombre: Paisaje Interior».

Como podemos comprobar, parece que la tendencia habitual ha sido aprovechar las diferentes intervenciones arquitectónicas para trasladar las obras, ya que son inmensamente pesadas. ${ }^{68}$ De hecho, su último cambio de ubicación hasta el momento se produjo dentro de la misma sala con motivo de la reestructuración museográfica emprendida tras la restauración del sepulcro de la infanta Leonor. ${ }^{69}$

65 Sobre las distintas obras de restauración, conservación y mejora llevadas a cabo durante el siglo XX, véase: GONZÁLEZ GONZÁLEZ: 1993, op. cit., pp. 307-308 y CASILLAS GARCÍA, José Antonio: El convento de Santo Domingo de Caleruega. 50 años como foco de dominicanismo. San Esteban, Salamanca, 2007, pp. 31-50. Centrándose la primera en el monasterio femenino y el segundo en el convento masculino. Aunque el apartado que recorre la historia previa del monasterio en el libro de Casillas García incluye algunos errores significativos, su relación de las obras de los nuevos edificios destinados a acoger a la comunidad de frailes es bastante exhaustiva.

66 Agradezco esta información, transmitida oralmente, a Sor Isidora Pérez Corral -priora del monasterio de manera intermitente entre los años 1959 y 1995-, que conoció la Anunciación en este emplazamiento y que, además, identifica la imagen del santo con el ejemplar del siglo XVI de madera policromada y tamaño natural conservado en el museo del monasterio, cuya ficha catalográfica encontramos en HERNÁNDEZ REDONDO, José Ignacio: «Santo Domingo de Guzmán». En: Las edades del hombre: la ciudad de seis pisos, catálogo de la exposición (El Burgo de Osma, 1997). Fundación Las Edades del Hombre, Madrid, 1997, pp. 226-227. Aunque la imagen de la sección pueda no corresponderse exactamente con la fisonomía de esta obra, los trabajos de Menéndez Pidal tienen ciertas licencias -como puede observarse si se comparan las escenas del retablo de la iglesia con su reflejo en los planos-. Por ello consideramos que, efectivamente, se podría estar queriendo representar esta obra que, por otra parte, es la única de las conservadas en el monasterio que coincide en tamaño y morfología.

67 Agradezco esta información, transmitida oralmente, a Sor Margarita Prieto Muela, actual priora del monasterio, que conoció la Anunciación cuando ya se encontraba en la antigua sala capitular.

68 Aunque no disponemos de datos precisos sobre el peso de las obras, así lo manifiesta Sor Adela Santamaría Rodríguez, que supervisó la salida del grupo en 2008 con motivo de su traslado a Soria.

69 Esta reestructuración, inaugurada el 1 de agosto de 2014, supuso que la Anunciación cediera la presidencia de la sala, que hasta entonces ostentaba desde el muro septentrional, al sepulcro de la infanta. Desde ese momento, el grupo escultórico está situado en el paño oriental, frente a la puerta de acceso. 


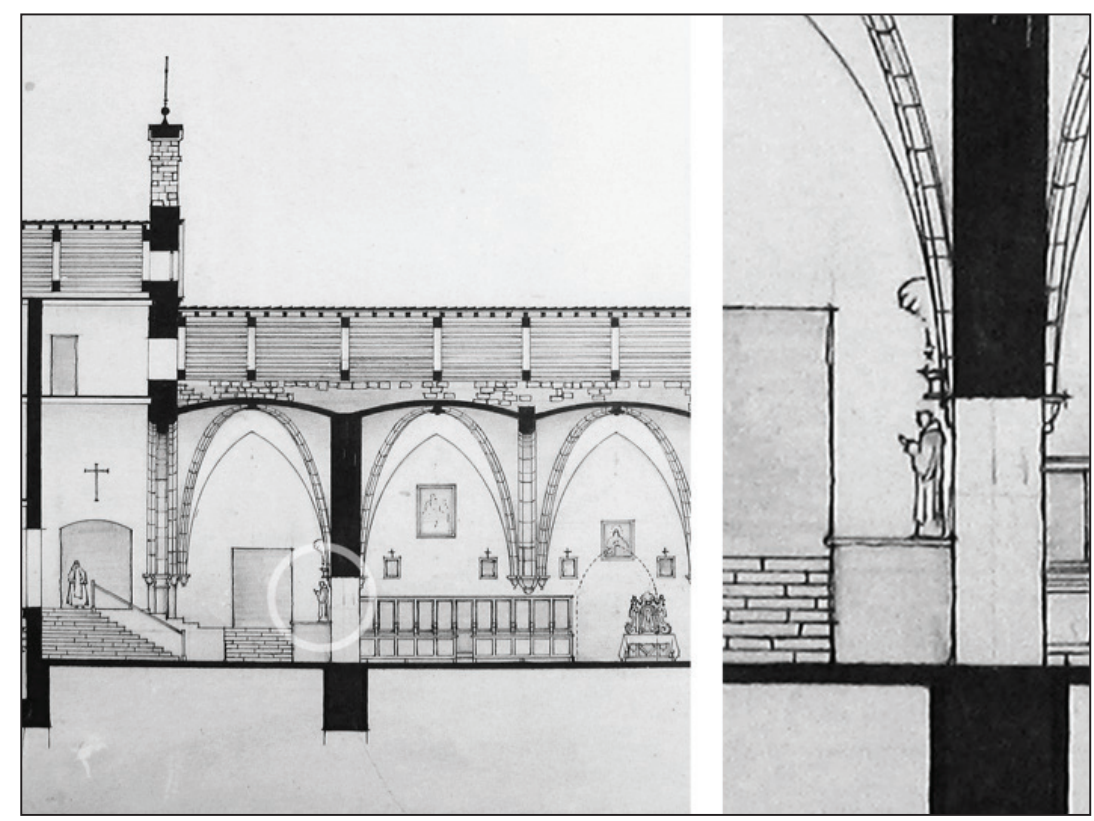

Fig. 3. Ubicación h. 1950 de la Anunciación del Real Monasterio de Santo Domingo de Caleruega (Burgos). Detalles de la sección longitudinal y trasversal de la iglesia del monasterio en los planos de Menéndez Pidal, 1949. [Foto: autor]

\section{Aspectos técnicos: características formales y estado de conservación}

Tanto la Virgen como Gabriel presentan un tamaño similar al natural, siendo la imagen de María ligeramente mayor que la del arcángel. ${ }^{70} \mathrm{~A}$ pesar de tratarse de esculturas exentas de bulto redondo, ambas figuras, realizadas en piedra caliza policromada, ${ }^{71}$ parecen haber sido concebidas para una contemplación frontal. ${ }^{72}$

El avanzado estado de gestación de la Virgen se manifiesta claramente en el vientre abultado. Sobre este apoya su mano derecha mientras que con la izquierda sostiene una filacteria que presenta restos de inscripciones superpuestas. María se encuentra de pie y viste una túnica de color azul muy oxidado ceñida bajo el pecho con un cíngulo que llega hasta sus pies. Este se oculta en su mayor parte tras el amplio manto blanco de revés rojo con el que la Virgen cubre su cabeza y que se cruza bajo el vientre formando abundantes pliegues hasta que es recogido en el brazo derecho - de una

70 Las medidas varían en función de la publicación consultada. En VV. AA.: 2001, op. cit., p. $27: 144$ x 55 x 33 cm. para Gabriel y 150 x 54 x 33 cm. para María; en PEREDA SAINZ: 2009, op. cit., p. $1: 144$ x 53 x 42 cm. para Gabriel y 149 x 58 x 36 cm. para María y en ZAPARAÍN YÁÑEZ: 2009, op. cit., p. $507: 145$ x 50 x $34 \mathrm{~cm}$. para Gabriel y 150 x 55 x 35 para María.

71 PEREDA SAINZ: 2009, op. cit., pp. 2 y 7 y ZAPARAÍN YÁÑEZ: 2009, op. cit., p. 507.

72 Así se apunta en PEREDA SAINZ: 2009, op. cit., p. 4. Lo cierto es que la parte trasera de ambas esculturas está poco trabajada, siendo más evidente en el caso de la Virgen que, además, presenta un pequeño orificio en la parte posterior de la cabeza que podría haber servido como parte de un mecanismo de anclaje. 


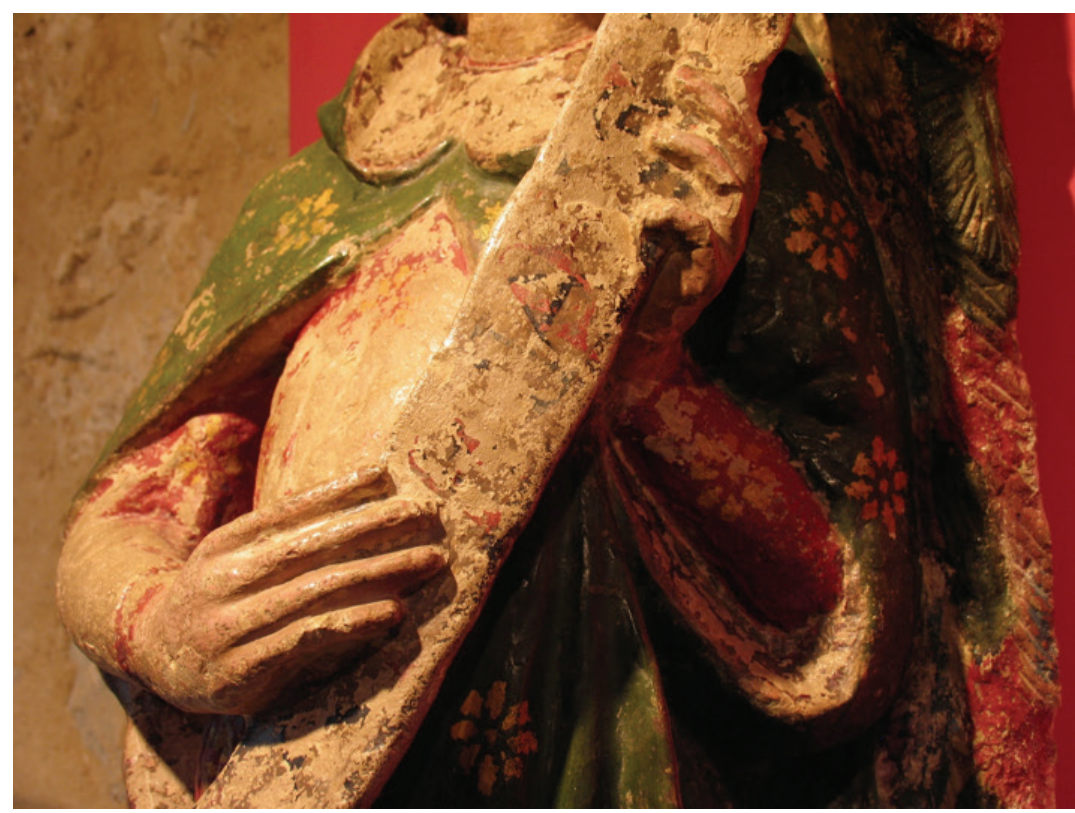

Fig. 4. Detalle del arcángel de la Anunciación, Real Monasterio de Santo Domingo, Caleruega (Burgos), primera mitad del siglo XIV. [Foto: autor]

manera característica que podemos observar en la mayoría de ejemplares castellanos de la tipología-. Finalmente, sobre su cuello alargado, y enmarcado por dos largos mechones rubios que llegan a la cintura, su rostro parece «insinuar una sonrisa». ${ }^{73}$

Por su parte, Gabriel, también de pie y situado a la derecha de María, ${ }^{74}$ porta con ambas manos una filacteria en la que apenas son visibles los restos de varias inscripciones (Fig. 4). Viste túnica roja y capa verde abotonada delante del cuello que también se cruza bajo el vientre para recogerse en su brazo izquierdo. Lleva los pies descalzos y tiene dos amplias alas de plumas rojas y verdes, habiendo perdido la parte superior de la derecha. El rostro sigue las mismas características que el de la Virgen y su cabello, también rubio, se peina en numerosos rizos acaracolados.

La restauración realizada con motivo de la participación del grupo en la exposición de Las Edades del Hombre se llevó a cabo entre diciembre de 2008 y enero de 2009. Los pormenores de esta labor, a cargo de Elsa Pereda Sainz, quedaron recogidos en la memoria que se depositó en el archivo del monasterio, ${ }^{75}$ la cual, junto con la ficha

73 VV. AA.: 2001, op. cit., p. 27.

74 A pesar de que el grupo se conserva descontextualizado, esta disposición se justifica a través de la comparación con las Anunciaciones de la variante castellana que aún se encuentran en su emplazamiento original y por la propia actitud de los personajes, especialmente la dirección de sus miradas. Además, resulta lógico pensar que la comunidad haya mantenido las esculturas según su disposición inicial.

75 PEREDA SAINZ: 2009, op. cit., pp. 9-16. 
catalográfica realizada por Zaparaín Yáñez, ${ }^{76}$ constituye el estudio monográfico más completo hasta la fecha.

El informe determinó que la Anunciación se encontraba relativamente en buen estado de conservación, mostrando la piedra el deterioro propio del envejecimiento. No obstante, tanto en la parte inferior -más expuesta a cambios de humedad y daños en los sucesivos traslados- como la posterior -tendente a entrar en contacto con otras superficies- de las esculturas, se advertían roturas y una erosión más marcada. En el caso de la pérdida de parte de las alas del arcángel, la restauradora considera que se produjo por la falta de sujeción entre dos piezas y no por un accidente. ${ }^{77}$

Por otra parte, Pereda Sainz afirma que, tras la observación minuciosa de las obras, se puede apreciar a simple vista la policromía original del conjunto a través de «pequeñas lagunas». De esta manera, bajo el cabello rubio de los personajes se encontraría un color oscuro, Gabriel vestiría túnica «roja rosa» y un manto violeta rojizo, mientras que María llevaría una túnica «marrón rosa», conservando el blanco del manto. ${ }^{78}$ Aun así, el tratamiento se enfocó únicamente a paralizar y neutralizar el deterioro de las piezas, sin alterar su aspecto actual. Se procedió a la limpieza del estrato superficial y a restablecer la cohesión de las capas de policromía, algo que no dificulta futuras intervenciones. ${ }^{79}$

\section{Análisis iconográfico}

La Anunciación es uno de los temas fundamentales del arte cristiano, pues no se trata de un simple pasaje de la vida de María, sino que constituye el fundamento de la naturaleza humana de Cristo y, por tanto, de la Redención. Por ello, y aprovechando la sencillez compositiva del episodio, ha sido representada prolíficamente en todas las épocas. ${ }^{80}$

76 ZAPARAÍN YÁÑEZ: 2009, op. cit., pp. 507-508.

77 Pereda Sainz considera que la obra no está realizada en un único bloque, sino que la conforman varias piezas ensambladas.

78 No obstante, debemos señalar que, tras la contemplación de la obra, no encontramos los restos polícromos indicados. En algunos casos, como el de la túnica «roja rosa» del arcángel (Fig. 4) creemos que las lagunas mencionadas podrían ser, en realidad, zonas más desgastadas de la capa externa de la policromía que, como ocurre en la túnica azul de la Virgen (Fig. 5), se muestran en un tono más claro.

79 PEREDA SAINZ: 2009, op. cit., p. 14.

80 En este apartado analizaremos exclusivamente las particularidades que presenta la Anunciación de Caleruega y, con ella, el resto de grupos de la Salutación Angélica en los que la Virgen aparece en avanzado estado de gestación. Para un estudio global del episodio y su iconografía, remitimos a las obras consultadas durante la realización del presente artículo. Para un análisis general: RÉAU: 1957, op. cit., pp. 174-194 y RODRÍGUEZ PEINADO, Laura: «La Anunciación», Revista Digital de Iconografía Medieval. 2014, vol. VI, nº 12, pp. 1-16. Disponible en web: https://www.ucm.es/data/cont/docs/621-2014-12-06-03.\%20Anunciaci\%C3\%B3n.pdf [última consulta: 16/02/2015]. Para una relación exhaustiva de las diferentes fuentes del pasaje: KRAEMER D'ANNUNZIO, Sonia: De donde nace la palabra. La Anunciación: textos, símbolos e iconografia. Tesis doctoral. Director: Andrés Ortiz-Oses. Universidad de Salamanca, Departamento de Historia del Arte - Bellas Artes, 2002. 


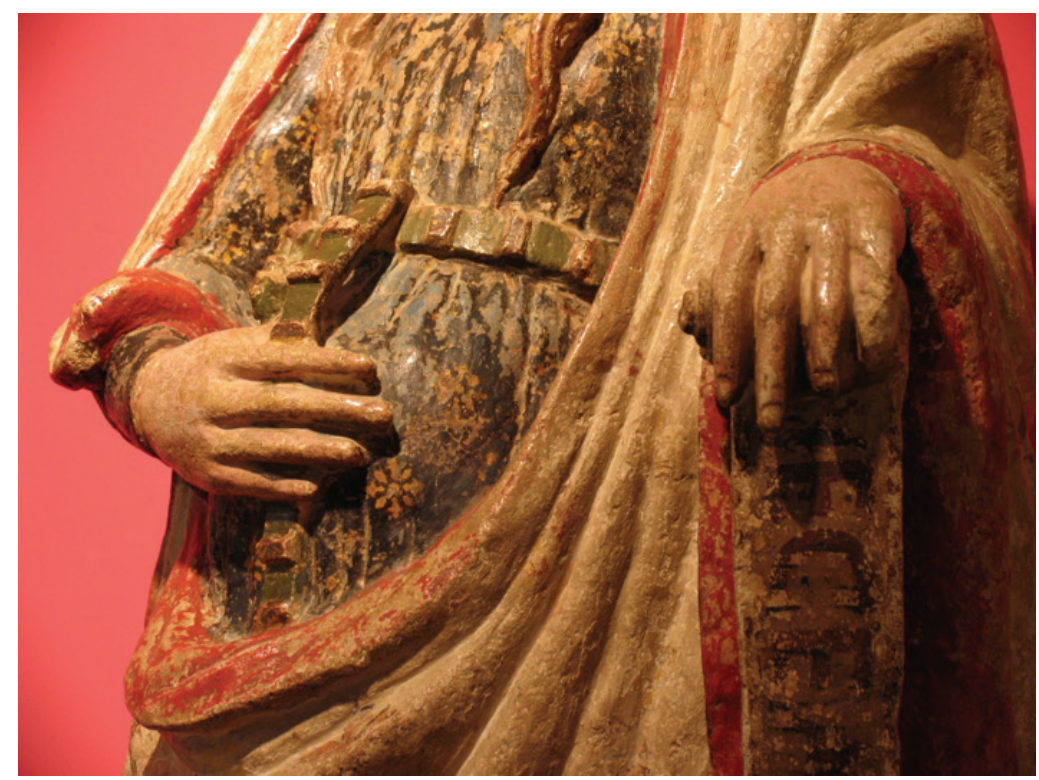

Fig. 5. Detalle de la Virgen de la Anunciación, Real Monasterio de Santo Domingo, Caleruega (Burgos), primera mitad del siglo XIV. [Foto: autor]

\subsection{Tema representado}

En el caso de Caleruega, la escena se reduce a sus dos protagonistas principales. La gestualidad del mensajero divino no está especialmente definida, ya que su tarea fundamental -el anuncio a la Virgen- se condensa en la filacteria que porta. Aunque únicamente es legible la palabra Gratia, se deduce el contenido que falta: Ave Maria gratia plena dominus tecum o la fórmula abreviada. ${ }^{81}$

El saludo recibe su réplica en el pergamino que sostiene María con la mano izquierda y en el que todavía pueden leerse las palabras: Ecce ancilla Domini. La aceptación de su misión constituye el punto clave del pasaje ya que, como acabamos de apuntar, se trata del inicio de la Salvación..$^{82}$ De esta manera, la Virgen se lleva la mano derecha al vientre, señalando que la Encarnación de Cristo ha dejado de ser una promesa para convertirse en una realidad. Este gesto potencia el papel de María como transmisora de vida, aspecto que fue especialmente impulsado durante el perío-

81 Un interesante y completo análisis sobre las palabras del arcángel en: KRAEMER D’ANNUNZIO: 2002, op. cit., pp. 34-36.

82 En este sentido, resulta interesante comprobar que las palabras de la Virgen no son únicamente el centro simbólico del episodio. Según sostiene Sonia Kraemer d'Annuzio en su tesis doctoral, la unidad literaria del pasaje de Lucas se extiende más allá del relato de la Anunciación, abarcando desde el Anuncio del Nacimiento de san Juan Bautista hasta la Visitación. A través de siete bloques que se confrontan métricamente siguiendo el arte hebreo del quiasmo, la respuesta de María queda como centro de la composición. KRAEMER D’ANNUNZIO: 2002, op. cit., pp. 31-32. 
do gótico. Pero, además, Gabriel le invita a alegrarse ${ }^{83}$ y ella, a través de su sonrisa, comunica la felicidad que le produce su futura maternidad, que supone la llegada del Redentor. ${ }^{84}$ Así, aunque no podamos verlo, Cristo se convierte en uno de los protagonistas de la escena. (Fig. 5)

La indumentaria de la Virgen -túnica, cíngulo y manto- refleja para algunos autores una clara influencia de la Antigüedad. ${ }^{85}$ Por su parte, los ropajes del arcángel se han identificado con el atuendo litúrgico. El mensajero se envuelve en una capa pluvial, prenda que se abrocha sobre el pecho y se empleaba en las grandes solemnidades litúrgicas, como la exposición del Sacramento de la Eucaristía, ${ }^{86}$ lo cual se ha relacionado, como veremos a continuación, con el desarrollo de la fiesta de la Expectación.

\subsection{El origen de la representación del embarazo}

Resulta complejo encontrar una justificación en las fuentes escritas que explique las razones que llevaron a representar tan vivamente el embarazo de María en este pasaje. Pues no son suficientes las meras referencias a la concepción o al embarazo, sino al avanzado estado de este. Así, la mayor parte de los investigadores lo relacionan con la fiesta de la Expectación y, por lo tanto, con la Virgen de la Esperanza o de la O que, como advirtió Trens, tiene su origen en la Virgen Apocalíptica o preexistente. ${ }^{87}$

Esta festividad, cuya paternidad se ha atribuido a san Ildefonso, también es conocida como Expectatio Partus. Fue introducida en el calendario litúrgico hispano tras el X Concilio de Toledo - celebrado en el año 656-, aunque no fue aprobada por el papado hasta el pontificado de Gregorio XIII, ya en el siglo XVI. Tenía lugar el 18 de diciembre y conmemoraba también la Anunciación que, en el rito romano, se festejaba el 25 de marzo, nueve meses antes de la Navidad. ${ }^{88}$ Sin embargo, la fecha coincidía con la Cuaresma y, a pesar de que tanto la Iglesia de Oriente como la de Occidente decretaron que debía celebrarse con total solemnidad, ${ }^{89}$ la hispana optó por cambiar de día. De esta manera, parece lógico que, debido a la proximidad del Nacimiento de Cristo, al representar el episodio se optase por materializar la avanzada gestación de María. ${ }^{90}$

No obstante, la adopción de la Expectatio Partus es relativamente temprana con respecto a la aparición de los primeros ejemplos de la variante iconográfica que estu-

83 KRAEMER D'ANNUNZIO: 2002, op. cit., p. 35.

84 ZAPARAÍN YÁÑEZ: 2009, op. cit., p. 507.

85 ZAPARAÍN YÁÑEZ: 2009, op. cit., p. 507.

86 FATAS CABEZA, Guillermo; BORRÁS GUALIS, Gonzalo: Diccionario de términos de Arte y elementos de Arqueología, Heráldica y Numismática. Alianza Editorial, Madrid, 2010, p. 68.

87 TRENS: 1947, op. cit., p. 75. Se hacen eco: FRANCO MATA: 1976, op. cit., p. 392; FRANCO MATA: 1998, op. cit., p. 362; NÚÑEZ RODRÍGUEZ: 1981, op. cit., pp. 410-413 y CRESPO HELLÍN: 1992, op. cit., pp. 39-41.

88 Más información en: NÚÑEZ RODRÍGUEZ: 1981, op. cit., p. 410; ALMEIDA, C. A. Ferreira de: A Anunciaçao na arte medieval em Portugal: estudo iconográfico. Instituto de História de Arte, Porto, 1983, p. 5; CARDOSO ROSAS: 1992, op. cit., pp. 78 y 206 y SÁNCHEZ AMEIJEIRAS: 2005, op. cit., p. 316.

89 MARTÍNEZ MARTÍNEZ: 2012, op. cit., p. 208.

90 MARTÍNEZ MARTÍNEZ: 2002, op. cit., p. 230. 
diamos. Al parecer, la fiesta había caído en desuso tras la implantación de la liturgia gregoriana -con la que entraba en conflicto- ${ }^{91}$ pero conoció un nuevo impulso durante el reinado de Alfonso X, que la incluyó en su marial al tiempo que se producía el hallazgo de los restos de san Ildefonso en Zamora, donde precisamente se concentran algunos de los grupos más tempranos. ${ }^{92}$ En este sentido, resulta significativo que los escritos del santo toledano no solo insistan en la virginidad perpetua de María y la Encarnación del Verbo, sino también en las palabras del arcángel, ${ }^{93}$ que en esta clase de Anunciaciones quedan enfatizadas por la presencia de la filacteria.

\subsection{La denominación de las Vírgenes embarazadas: un apunte terminológico}

Como indicó Martínez Martínez, la simultaneidad de las fiestas de la Anunciación y la Expectación ha generado una variada terminología para referirse a estos grupos y especialmente a sus Vírgenes. ${ }^{94}$ Entre la enumeración de advocaciones ofrecida por Réau ya encontramos las de «Señora de la Expectación», «Virgen de la Esperanza» $\mathrm{y}$ «Virgen de la $\mathrm{O} »{ }^{95}$ Las tres están estrechamente vinculadas a la festividad del 18 de diciembre y, de hecho, el nombre de esta última parece hacer referencia a las siete antífonas cantadas la víspera y que empiezan con dicha letra. Por ello, sobre todo en Galicia y Portugal, se ha generalizado la denominación de «Anunciación con Virgen de la O».

Sin embargo, consideramos que, si bien esta terminología es válida, particularmente para las dos regiones mencionadas, se puede encontrar una más correcta, al menos para el caso castellano. Sánchez Ameijeiras que, como ya indicábamos anteriormente, ha abordado el estudio de esta iconografía en los últimos años, se refiere a los grupos como «Anunciaciones Preñadas», denominación que ha tenido escasa fortuna entre los investigadores. Gómez Moreno ya mostró su rechazo cuando escribió sobre la Virgen de la Anunciación de la catedral leonesa. En su Catálogo monumental de la provincia de León se puede leer que la escultura le resultaba «antipática y en armonía con el mal gusto de su advocación» ${ }^{96}$ Años después, Franco Mata consideró que se trataba de una «advocación ciertamente exenta de elegancia». ${ }^{97}$

Independientemente de sus connotaciones contemporáneas, lo cierto es que el término «Preñada» aparece con frecuencia en la documentación medieval para referirse a estas imágenes. En el caso de la Virgen de la Pulchra Leonina, Raimundo Rodríguez Vega apuntó que precisamente así «se llama siempre en los documentos, Nues-

\footnotetext{
91 Martínez Martínez señala que la recepción de la liturgia romana en Castilla contó con fuertes reticencias y que, en numerosas ocasiones, encontramos la simultaneidad de ambas festividades. Para la autora, esta sería la causa de la convivencia entre las representaciones de la Anunciación en las que la Virgen está embarazada y aquellas en las que no lo está. MARTÍNEZ MARTÍNEZ: 2012, op. cit., pp. 209-210.

92 Así lo hizo notar SÁNCHEZ AMEIJEIRAS: 2009, op . cit., p. 252.

93 NÚÑEZ RODRÍGUEZ: 1981, op. cit., p. 413.

94 MARTÍNEZ MARTÍNEZ: 2012, op. cit., p. 217.

95 RÉAU: 1975, op. cit., p. 90.

96 GÓMEZ MORENO: 1925-1926, op. cit., p. 247.

97 FRANCO MATA: 1976, op. cit., p. 392.
} 
tra Señora la Preñada» ${ }^{98}$ siendo una advocación que se corrobora con la existencia de cofradías como la de Toro. ${ }^{99}$ Además, también encontramos esta denominación en obras literarias como el Cancionero musical de Astudillo, que cuenta con una composición en la que se repiten las siguientes palabras en boca de la Virgen: «Preñada soy, preñada / de un alto Enperador / amada e guardada / de Dios, el mi Señor». ${ }^{100}$ En definitiva, se trata de un término que cuenta con una amplia tradición histórica documentada.

\section{Las variantes iconográficas de Castilla, Galicia y Portugal}

A pesar de compartir una serie de características, las Anunciaciones Preñadas no constituyen un grupo homogéneo y presentan diversas variantes sobre las que no se ha llamado la atención con anterioridad. Como avanzábamos al inicio, estas se corresponden con los territorios de Castilla, Galicia y Portugal y sus características particulares resultan más evidentes en los ejemplares de escultura monumental que en los de menores dimensiones.

El grupo de Caleruega se enmarca perfectamente dentro de la variedad castellana, a la que pertenece tanto geográfica como iconográficamente. Se trata precisamente del subgrupo más extendido y homogéneo. Al parecer, tienen su origen en el citado grupo de la catedral de León, donde la Virgen ya es mencionada en 1289. ${ }^{101} \mathrm{Si}$ bien es cierto que se aprecian diferencias estilísticas entre las esculturas de Gabriel y María, como ya señaló Franco Mata, ${ }^{102}$ su impronta se advierte en el grupo de la colegiata de San Isidoro de la misma ciudad y se puede encontrar en la mayoría de los grupos posteriores. Además de los ejemplos contabilizados en Castilla, adscribimos también a esta variante las Anunciaciones de Tarazona, en Zaragoza, y Laguardia, que actualmente forma parte de la provincia de Álava pero que, debido a su posición fronteriza, durante la Edad Media perteneció a Navarra en diversas ocasiones hasta que pasó definitivamente a Castilla en el año 1461. ${ }^{103}$ (Fig.6)

98 RODRÍGUEZ VEGA: 1947, op. cit., p. 147. Bajo esta advocación habría sido recogida en el testamento del obispo Martín Fernández en 1288 según ARA GIL: 1995, op. cit., p. 284. No obstante, Franco Mata no pudo corroborar la referencia: FRANCO MATA: 1998, op. cit., p. 360, nota 5. De hecho, si consultamos en RUIZ ASENCIO, José Manuel; MARTÍN FUERTES, José Antonio: Colección documental del archivo de la Catedral de León, IX (1269-1300). Centro de Estudios e Investigación «San Isidoro», Caja España de Inversiones, Caja de Ahorros y Monte de Piedad, Archivo Histórico Diocesano, León, 1994, la transcripción del documento (pp. 347-349), comprobamos que, efectivamente, no aparece ninguna mención de la escultura. Sin embargo, en un documento fechado el 24 de marzo de 1289 que da noticia de la muerte del mencionado obispo y de sus donaciones al cabildo, se nombra una imagen de la Virgen representada encinta: «Alioquim in cruce ecclesie coram ymagine Beate Marie, que ipsam fuisse grauidam representat, ac insuper quod post obitum ipsius domine in proxima sinodo capitulum ipsum procuret quod singuli presbiteri ciuitatis et diocesis Legionensis bis missam de requie pro anima sua cantent» (p. 354).

99 NAVARRO TALEGÓN: 1993, op. cit., p. 301.

100 CÁTEDRA GARCÍA, Pedro Manuel: Liturgia, poesía y teatro en la Edad Media: estudios sobre prácticas culturales y literarias. Gredos, Madrid, 2005, pp. 242-244.

101 Ver nota 98.

102 FRANCO MATA: 1976, op. cit., p. 394.

103 AZCÁRATE RISTORI, José María: Arte gótico en España. Cátedra, Madrid, 1990, p. 215. 


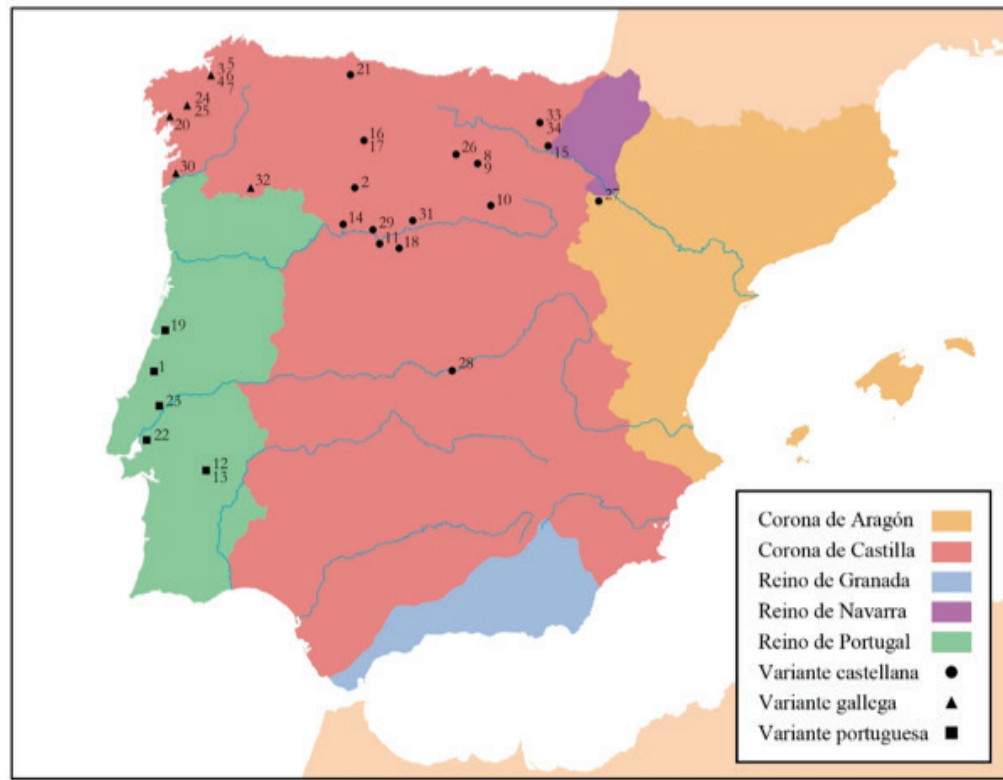

1. Batalha (Leiria), Monasterio de Santa Maria da Vitória

2. Benavente (Zamora), Iglesia de Santa María del Azogue

3. Betanzos (A Coruña), Iglesia de San Francisco

4. Betanzos (A Coruña), San Francisco, arcosolio sepulcral vacío ocupado por una Piedad

5. Betanzos (A Coruña), San Francisco, sepulcro de un hombre con hábito franciscano

6. Betanzos (A Coruña), San Francisco, sepulcro de una dama de la familia de los Pardo y Aguilar

7. Bentazos (A Coruña), Iglesia de Santa María del Azogue

8. Burgos (Burgos), Catedral, sepulcro de Díaz Peñafiel

9. Burgos (Burgos), Catedral, sepulcro de Lope de Fontecha

10. Caleruega (Burgos), Real Monasterio de Santo Domingo

11. Castronuño (Valladolid), actualmente en el Museo Diocesano y Catedralicio de Valladolid

12. Évora (Évora), Catedral

13. Évora (Évora), Catedral, Capela do Fundador

14. La Hiniesta (Zamora), Iglesia de Santa María la Real

15. Laguardia (Álava), Iglesia de Santa María de los Reyes

16. León (León), Catedral
17. León (León), Real Colegiata de San Isidoro 18. Medina del Campo (Valladolid), Iglesia de Santiago

19. Montemor-o-Velho (Coimbra), Castillo, Iglesia de Santa Maria da Alcáçova

20. Noia (A Coruña), Iglesia de San Martín

21. Oviedo (Asturias), Catedral

22. Samora Correira (Santarém), Iglesia de Nossa Senhora da Oliveira

23. Santarém (Santarém), Iglesia de Santa Clara

24. Santiago de Compostela (A Coruña), Catedral

25. Santiago de Compostela (A Coruña), Iglesia de Santa Maria Salomé

26. Sasamón (Burgos), Colegiata de Santa María la Real

27. Tarazona (Zaragoza), Catedral

28. Toledo (Toledo), Museo del Greco (procedencia original desconocida)

29. Toro (Zamora), Colegiata de Santa María la Mayor

30. Tui (Pontevedra), Catedral

31. Valladolid (Valladolid), Hospital de Esgueva, actualmente en los depósitos del Museo Nacional de Escultura de Valladolid

32. Verín (Ourense), Castillo de Monterrei, Iglesia de Santa María de Gracia

33. Vitoria (Álava), Catedral Vieja

34. Vitoria (Álava), Catedral Vieja, tímpano de la portada principal

Fig. 6. Distribución de los grupos de la Anunciación Preñada (fronteras h. 1300). [Mapa: autor. Fronteras basadas en: LÓPEZ TOSSAS, Emili (ed.): Atlas histórico de España. Larousse, Barcelona, 2012.] 
Según algunos autores, esta iconografía habría llegado a Portugal desde el territorio castellano. ${ }^{104}$ No obstante, ciertos investigadores lusos sitúan el origen de la tipología en su propia patria. ${ }^{105}$ En cualquier caso, parece existir unanimidad en cuanto a su aparición en Galicia, que se tiende a vincular con la instalación de un taller procedente de Coimbra en la ciudad de Santiago de Compostela. ${ }^{106}$ Sin lugar a dudas, el grupo de la catedral compostelana recoge perfectamente las características del prototipo de Virgen portuguesa e, independientemente de si fue realizado en el siglo XIV o en el XV, ${ }^{107}$ son muchas las influencias que de él se reflejan en otras esculturas gallegas. Esta estrecha relación artística entre ambas orillas del Miño nos lleva a plantearnos la posibilidad de que, en realidad, se trate de una misma variante galaico-portuguesa. Sin embargo, en el presente estudio optaremos por distinguir ambos subgrupos teniendo en cuenta la relativa homogeneidad de las Anunciaciones gallegas. Situación que podría cambiar en función de la aparición de nuevos grupos que variaran las estadísticas.

Por otra parte, y sin intención de hacer una relación exhaustiva de cada uno de los grupos, cuyas particularidades se pueden consultar en las tablas incluidas al final del artículo, ${ }^{108}$ a continuación procedemos a realizar un recorrido por las características principales de las tres variantes que, más adelante, sistematizaremos en el apartado de las conclusiones.

104 FRANCO MATA: 1976, op. cit., p. 393.

105 Concretamente en las jambas de la portada de San Salvador de Bravães: CARDOSO ROSAS: 1992 , op. cit., p. 78. Sin embargo, su mal estado de conservación y su ambigüedad iconográfica hacen que no todos los historiadores del arte portugueses compartan esta afirmación: GRAF, Gerhard N.: Portugal. Vol. 2. Encuentro, Madrid, 1988, pp. 236-237.

106 MANSO PORTO; YZQUIERDO PERRÍN: 1996, op. cit. p. 432 y BARRAL RIVADULLA: 2007, op. cit., p. 16.

107 Algunos autores lo fechan en el siglo XV, vinculándolo al arzobispo Lope de Mendoza, mientras que para otros pudo ser una donación de la reina lusa Isabel de Aragón tras una peregrinación a Compostela. MANSO PORTO; YZQUIERDO PERRÍN: 1996, op. cit. p. 436 e YZQUIERDO PEIRÓ: 2011, op. cit., p. 74. Precisamente al círculo de la reina Santa pertenecía el maestro Pedro, al que se atribuyen numerosas Vírgenes de la $\mathrm{O}$ en Portugal. Para más información sobre su mecenazgo: MACEDO, Francisco: «Isabel de Aragão, Rainha de Portugal e a Arte em Coimbra». En: CAAMAÑO, Jesús María (coord.): Relaciones artísticas entre Portugal y España. Junta de Castilla y León, Valladolid, 1986, pp. 155-163.

108 Estas tablas recogen los grupos inventariados por los diversos autores consultados, así como aquellos que incluimos por primera vez en este estudio, como la Anunciación de la fachada sur de la colegiata de Santa María la Real de Sasamón, el capitel del claustro de la catedral de Oviedo y los tres sepulcros del interior de San Francisco de Betanzos. Asimismo, no incorporamos algunas de las esculturas recogidas en las siguientes publicaciones: ARA GIL: 1977, op. cit., pp. 170-171. La autora sopesa que la Virgen de un Calvario procedente de Villavicencio, en el Museo Diocesano y Catedralicio de Valladolid, formase parte de una Anunciación, pero no hemos podido estudiar la pieza directamente para corroborarlo; ARA GIL: 1995, op. cit., p. 284. La autora incluye la Anunciación de la catedral de Palencia -que, como ya explicamos en la nota 37, no consideramos parte de esta tipología-; LECHNER: 1981, op. cit., p. 338. El autor menciona una Virgen encinta del tesoro de la catedral de Santiago de Compostela, indicando que seguramente formó parte de una Anunciación. Aunque, de nuevo, no hemos podido verificarlo; MARTÍNEZ MARTÍNEZ: 2012, op. cit., pp. 215-217. La autora valora la posibilidad de incluir el ángel aislado de la colegiata de Sasamón pero indica que carece de datos precisos para hacerlo. 


\subsection{Gestualidad}

El hecho de que Gabriel porte una filacteria no es exclusivo de la Anunciación Preñada. Sin embargo, se trata de un rasgo habitual en estas representaciones. En el caso de la escultura monumental castellana, es sostenida con las dos manos, que se separan tendiendo a los extremos de la misma, destacando su verticalidad. Así ocurre en Caleruega y los grupos que aún conservan la filacteria, como los de San Isidoro de León y Santa María la Mayor de Toro. Por su parte, en los ejemplos de menor formato, el pergamino es sustentado con la mano izquierda mientras que se alza la derecha en dirección a la Virgen. Sirvan como ilustración las Anunciaciones de los sepulcros de Díaz Peñafiel y Lope de Fontecha en la catedral de Burgos.

También existen variaciones en los arcángeles gallegos. Los que siguen el modelo compostelano, como los de Santa María del Azogue en Betanzos y Santa María Salomé en la propia ciudad de Santiago, sujetan la filacteria con las dos manos a la altura de la cintura. No obstante, existen casos en los que el arcángel adopta una posición parecida a la del prototipo castellano -iglesia de Santa María de Gracia en el castillo de Monterrei- y no faltan los grupos en los que Gabriel señala a María, como ocurre en el de la portada lateral de la iglesia de San Francisco de Betanzos. ${ }^{109}$

En el caso de la Virgen, el gesto fundamental que define a esta clase de Anunciaciones es la colocación de una de sus manos sobre el vientre. En los ejemplares castellanos, María apoya la derecha, salvo en el grupo de la fachada sur de Santa María la Real de Sasamón que, al igual que la mayoría de las Vírgenes gallegas, lo hace con la izquierda. ${ }^{110}$ En Portugal encontramos ambos modelos pero, tal y como ocurre con los ejemplares lusos de Gabriel, no disponemos de datos suficientes para señalar una preferencia. ${ }^{111}$

Con todo, la diferencia básica entre las distintas variantes se encuentra en la otra mano de María. En Castilla suele sostener una filacteria, rota o desaparecida la mayor parte de las veces, que recoge la respuesta a las palabras del arcángel y que aparece excepcionalmente en Portugal en la catedral de Évora. Pero en los ejemplos más tardíos y en la escultura de pequeño formato solemos encontrar un libro, motivo frecuente en la Anunciación que alude a la profecía de Isaías. Por su parte, las Vírgenes portuguesas alzan una de sus manos en señal de saludo, decantándose las gallegas por la derecha, salvo en los grupos de escultura monumental de Betanzos que, en lugar de elevarla, la emplean para recoger los pliegues del manto. ${ }^{112}$

109 Los sucesivos cambios de naturaleza experimentados por el espacio en el que se sitúa esta portada dificultan el estudio del grupo, cuya disposición actual podría deberse a alguna de las sucesivas intervenciones que afectaron a su entorno ya desde la propia Edad Media.

110 En el caso de dos de los grupos ubicados en los sepulcros del interior de San Francisco de Betanzos, la Virgen apoya su mano derecha sobre el vientre. En ambas ocasiones, María está situada a la derecha, con lo que la mano que reposa sobre el abdomen se sitúa hacia el interior del arcosolio. Sin embargo, en la Anunciación en la que la madre de Cristo emplea la mano izquierda, está colocada a la izquierda, con lo que, de nuevo, esta mano queda hacia el interior del arcosolio. Sería interesante valorar esta situación.

111 Lechner se sorprendió de que la Virgen del grupo de la Capela do Fundador de la catedral de Évora apoyase su mano derecha pero también es un gesto habitual. LECHNER: 1981, op. cit., p. 340.

112 También en Betanzos, los mencionados grupos de los sepulcros de la iglesia de San Francisco (ver nota 110) difieren de la variante, pues las tres Vírgenes sostienen un libro en lugar de alzar la mano. 


\subsection{Indumentaria}

También podemos valernos de los ropajes para acotar los subgrupos. Los arcángeles aparecen descalzos y suelen vestir prendas litúrgicas -que se han vinculado a la célebre casulla que la Virgen impuso a san Ildefonso, ya que, como señalamos anteriormente, este santo está estrechamente vinculado a la fiesta de la Expectación- ${ }^{113}$ salvo en el caso de las esculturas de menor formato, donde van ataviados con túnica y manto de aspecto clásico, y en la Anunciación de Santa María la Real de la Hiniesta. ${ }^{114} \mathrm{La}$ capa pluvial se convierte en el distintivo de los mensajeros de la variedad castellana, que la recogen en su brazo izquierdo, mientras que los gallegos visten alba, dalmática y manípulo, ${ }^{115}$ aunque, en ocasiones, prescinden de este último. No obstante, según algunos autores, el Gabriel de Toro vestiría alba y casulla, ${ }^{116}$ al igual que el de Vitoria, que además llevaría dalmática. ${ }^{117}$

En el caso de la Virgen, la base de su indumentaria la constituyen la túnica y el manto. La Preñada leonesa cubre su cabeza con un velo cruzado que aún se mantiene en las imágenes de San Isidoro de León y la Hiniesta. Sin embargo, lo usual, tanto para las esculturas castellanas como para las gallegas y portuguesas, es que lo haga con un velo o con el propio manto, como ocurre en Caleruega. En ocasiones se adorna con una corona o una diadema de pedrería, aunque hay casos en los que parecen haber sido colocadas con posterioridad -Anunciación de la catedral de Évora-. El manto se cruza bajo el vientre de manera sistemática, quedando recogido en el brazo derecho en los ejemplos de la variedad castellana. El cíngulo suele aparecer en las Vírgenes de Castilla, aunque también lo encontramos en casos como el de Monterrei. A diferencia del arcángel, la Virgen está calzada, siendo visibles sus zapatos en la mayoría de conjuntos gallegos y portugueses. En ocasiones aparece el jarrón de azucenas propio la Salutación Angélica que tradicionalmente se ha vinculado a la pureza de María. ${ }^{118}$

\subsection{Ubicación y posibles funciones}

Tal y como sucede en el caso de Caleruega, una buena parte de estas Anunciaciones se encuentra actualmente descontextualizada. No obstante, también existen grupos

\footnotetext{
113 LAHOZ GUTIÉRREZ: 2002, op. cit., p. 221 y SÁNCHEZ AMEIJEIRAS: 2009, op. cit., p. 254.

114 SÁNCHEZ AMEIJEIRAS: 2009, op. cit., p. 251. Considera que no lleva vestimentas litúrgicas.

115 La dalmática es una prenda litúrgica sin mangas, propia de los diáconos, que cubre el alba -túnica interior-, y el manípulo es un ornamento que se ciñe al brazo dejando caer sus extremos.

116 SÁNCHEZ AMEIJEIRAS: 2009, op. cit., p. 251. NAVARRO TALEGÓN: 1993, op. cit., no describe los ropajes pero consideramos que se trata de una capa pluvial y no de una casulla, ya que esta prenda litúrgica no posee la apertura frontal que muestra la escultura toresana, producida por el recogimiento de la capa.

117 FRANCO MATA: 1976, op. cit., p. 399.

118 GONZÁÑEZ MONTAÑES, Julio Ignacio: Drama e iconografía en el arte medieval peninsular (Siglos XI-XV). Tesis doctoral. Director: Víctor Nieto Alcaide. Universidad Nacional de Educación a Distancia, Departamento de Historia del Arte, 2002, p. 215, nota 30. Disponible en web: http://www.teatroengalicia.es/ tesis.htm [última consulta: 13/02/2015]. Recoge la relación que Mâle hizo entre el jarrón y la primavera por el 25 de marzo, apreciación que se complica en esta clase de Anunciaciones por su relación con la fiesta de la Expectación.
} 


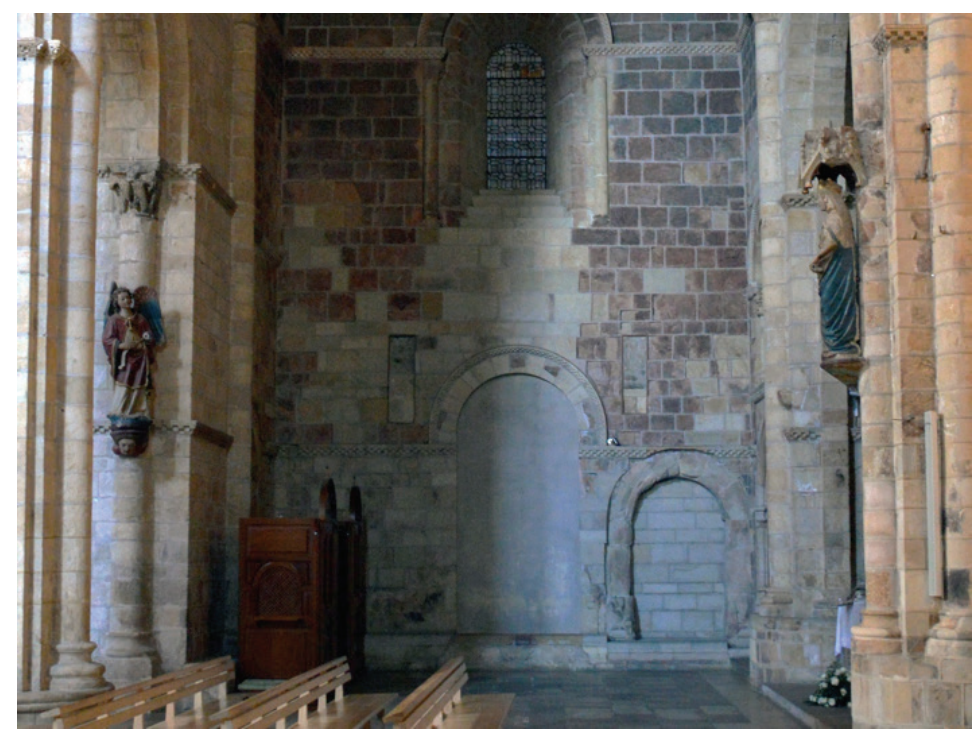

Fig. 7. Anunciación, Real Colegiata de San Isidoro, León (León), finales del siglo XIII.

[Foto: autor]

que se conservan en su emplazamiento original. En los ejemplos de escultura monumental castellana destaca su colocación sobre peanas a cierta altura en los pilares del crucero -Benavente-, la nave mayor - Toro- o el acceso a una de las capillas laterales, como ocurre en San Isidoro de León (Fig. 7) y está documentado en la catedral de dicha ciudad. ${ }^{119}$ Además, conocemos la existencia de altares, como los desaparecidos del grupo de la catedral de Compostela o los que aún se conservan en la iglesia del castillo de Montemor-o-Velho y la catedral de Évora, si bien estos últimos se realizaron con posterioridad a las obras, ${ }^{120}$ como hemos visto que ocurrió, aunque con menos suntuosidad, en la Anunciación calerogana.

Por otra parte, también encontramos estos grupos en las fachadas de los edificios, como sucede en Sasamón y está gráficamente documentado en el hospital de Esgueva de Valladolid antes de su derribo. Este último caso resulta particularmente interesante, pues se trataría del único ejemplo conservado perteneciente a una arquitectura civil. Sin embargo, recientemente se ha especulado sobre su posible origen en la también desaparecida iglesia de San Miguel de la misma ciudad. ${ }^{121}$ Esta disposición podemos encontrarla igualmente en edificios gallegos, a ambos lados de la portada -Santa María Salomé de Santiago de Compostela y San Francisco de Betanzos- o en sendas hornacinas -Santa María del Azogue de Betanzos-. Asimismo, se colocan en los pilares del pórtico, como en la catedral de Vitoria, pudiendo llegar a alcanzar una

119 RODRÍGUEZ VEGA: 1947, op. cit. [2013, p. 147].

120 Al menos en el caso de la catedral de Évora sabemos que es barroco. ESPANCA: 1946, op. cit., p. 2.

121 URREA FERNÁNDEZ, Jesús; SOLÉ ELVIRA, Gloria: El retablo mayor de la iglesia de San Miguel de Valladolid. Fundación del Patrimonio Histórico de Castilla y León, 2007, p. 53, nota 10. 
altura considerable - catedral de Tui-. Tampoco faltan los grupos en arquivoltas -San Martín de Noia- o el propio tímpano, tal y como sucede en Laguardia o en la citada catedral vitoriana.

Pueden aparecer también en capillas fúnebres como la Capela do Fundador de la catedral de Évora ${ }^{122} \mathrm{o}$ en los propios sepulcros, como los citados burgaleses o el de Leonor Afonso en Portugal. Este último ejemplo está trabajado en relieve, al igual que los capiteles del claustro de la catedral de Oviedo y los de la entrada de la sala capitular del monasterio de Batalha, donde encontramos sendos ejemplares.

Hasta ahora hemos enumerado los modelos pétreos y cabría preguntarse por el emplazamiento de las esculturas realizadas en madera. Únicamente conservamos dos ejemplos: la Anunciación del Museo del Greco de Toledo y la Virgen Preñada de Medina del Campo. ${ }^{123}$ Aunque son pocos, teniendo en cuenta la fragilidad del material y el rechazo que acabaron despertando estas imágenes, es posible que el número fuese mayor, pero desconocemos si tuvieron usos y ubicaciones similares.

En cualquier caso, podemos concluir que las Anunciaciones Preñadas no ocuparon espacios distintos a los del resto de las representaciones de la Salutación Angélica. Del mismo modo, tampoco existe una marcada diferenciación entre los emplazamientos de los grupos de las diversas variantes. Con todo, es posible apuntar que, en cuanto a la escultura monumental, mientras que los ejemplares gallegos parecen tendentes a situarse en el exterior, los grupos de Castilla y Portugal suelen ubicarse en espacios preferentes del interior de los templos.

Esto ha llevado a Sánchez Ameijeiras, centrada precisamente en el caso castellano, a plantearse la posibilidad de que estas Anunciaciones no fueran imágenes devocionales sino «obras monumentales» destinadas a una audiencia laica y que se relacionasen con el adoctrinamiento de los judíos. Una teoría sugerente cuya aplicación se complica en el caso calerogano pues, como ya apuntó Martínez Martínez, se trata de un monasterio de clausura femenino situado en una villa donde no destacó la presencia de judíos. ${ }^{124}$

Una última hipótesis interesante sería la de plantear el uso litúrgico de estas imágenes. A modo de ejemplo, se sabe que en la catedral de Santiago de Compostela se celebraba solemnemente la fiesta de la Expectación, incluyendo el uso de mecanismos para hacer descender una figura de las bóvedas, que con toda probabilidad sería una paloma. ${ }^{125}$ Aunque no está documentado el uso del grupo catedralicio reseñado, son muchos los ejemplos de dramas litúrgicos que emplean esculturas y Julio Ignacio González Montañés, que ha estudiado el tema, no descarta del todo esta posibilidad. ${ }^{126}$

122 LECHNER: 1981, op. cit., p. 340.

123 A pesar de que la Virgen encinta de la iglesia de Santiago de Medina del Campo ha sido considerada como una imagen aislada, Ara Gil aportó documentación que apunta a su posible origen como parte de una Anunciación. ARA GIL: 2006, op. cit., pp. 125-127.

124 MARTÍNEZ MARTÍNEZ: 2012, op. cit., p. 207.

125 GONZÁLEZ MONTAÑÉS: 2002, op. cit., p. 217.

126 Agradezco esta información a Julio Ignacio González Montañés. 


\section{Conclusiones}

Tras este breve repaso de las Anunciaciones Preñadas de la península ibérica, podemos afirmar que el grupo de Caleruega no fue un caso excepcional en lo que a iconografía se refiere. El rechazo que produjo esta clase de imágenes en los hombres de los siglos XVIII y XIX bien pudo ser el causante del paulatino olvido de la tipología, pero los sucesivos estudios que han tratado la materia han llamado la atención sobre su importancia.

No obstante, se trata de un campo de investigación en el que aún queda mucho por hacer. En este sentido, resulta fundamental la apuesta por trabajos que analicen la totalidad de los ejemplares de forma global, obviando las fronteras actuales entre España y Portugal. Además, para llegar a conclusiones sólidas, es necesario inventariar el mayor número de obras posibles. Si en los últimos años se ha ido demostrando que determinadas esculturas que se consideraban independientes -como las ya citadas Vírgenes de Medina del Campo y la catedral de León- formaron parte de una Anunciación, el número de grupos es susceptible de aumentar.

A la luz de los datos actuales, parece que esta variante iconográfica disfrutó de una gran aceptación en los reinos de Castilla y Portugal, siendo prácticamente nula su presencia en Navarra y Aragón. Aunque debemos tomar estas deducciones con cautela, pues no conocemos el alcance total de las pérdidas, consideramos que, a grandes rasgos, se pueden distinguir tres variantes iconográficas de la Anunciación Preñada: una en Portugal y dos en Castilla -por un lado Galicia y por otro la mitad norte de la Corona-. ${ }^{127}$

Estos subgrupos, cuyo número y características podrían modificarse ligeramente en función de la contabilización de nuevos ejemplares, se pueden distinguir al comparar su iconografía. La diferencia principal se encuentra en la actitud de la Virgen. En el caso castellano, apoya su mano derecha sobre el vientre mientras que con la izquierda sujeta una filacteria o un libro. Viste túnica, manto cruzado y, en la mayoría de las ocasiones, cíngulo. Mientras, el arcángel porta con ambas manos una filacteria y viste túnica y capa pluvial. Por su parte, las Vírgenes gallegas apoyan la mano izquierda sobre el vientre y alzan la mano derecha en señal de saludo. Dejan a la vista sus zapatos y añaden el velo a su indumentaria. Los mensajeros visten alba, dalmática y, en algunas ocasiones, también manípulo. En cuanto al caso de Portugal, que aún precisa de un estudio en profundidad, no disponemos de datos suficientes como para establecer una constante en sus Anunciaciones, que se asemejan extraordinariamente a las de Galicia, ya que sus Vírgenes también alzan la mano que no reposa sobre el vientre.

El origen de estas Anunciaciones se ha fechado a finales del siglo XIII, situándose en el XIV su época de mayor apogeo. Sin embargo, sería conveniente realizar análisis técnicos que solventasen las disputas cronológicas, facilitando así la comprensión del

127 Como puede observarse en el mapa con la distribución de los grupos (Fig. 6), las Anunciaciones de la variante castellana se concentran en el tercio norte del reino. De hecho, el único ejemplar que se encuentra más al sur de la ribera del Duero es el conservado en el Museo del Greco de Toledo y desconocemos su procedencia original. 
desarrollo de la tipología y la historia misma de cada una de las piezas. Disponiendo de fechas más concretas podríamos enfrentarnos a cuestiones específicas como la comitencia o la autoría de las obras que, en el caso de Caleruega, aún plantean numerosos enigmas.

Las teorías sobre la realización del grupo en la primera mitad del siglo XIV y su primitivo emplazamiento en la iglesia del monasterio encajarían perfectamente con el resto de ejemplares castellanos del momento. Sin embargo, su ubicación en el seno de una comunidad femenina de clausura es una particularidad que carece de parangón en el reino, pues la mayoría se encuentra en catedrales y templos relevantes para sus respectivas poblaciones. La referencia más cercana la encontramos en San Francisco de Betanzos, antiguo convento franciscano, donde tres de las cuatro Anunciaciones -pertenecientes a la variante gallega- aparecen ligadas al ámbito funerario y todas pueden ponerse en relación con el emblema de su promotor, Fernán Pérez de Andrade. ${ }^{128}$

Es probable que una mayor comprensión del posible papel desempeñado por estas imágenes en la liturgia de la Expectatio Partus nos ayudaría a comprender mejor la distribución de estos grupos. Al igual que sería interesante profundizar en las razones teológicas que llevaron a representar a la madre de Cristo en avanzado estado de gestación en el preciso instante de la visita del arcángel. Toda esta información nos permitiría abordar íntegramente el estudio de la Anunciación de Caleruega y quizá algún día podamos conocer más datos sobre su encargo e historia. Pero, mientras tanto, continuará siendo una familiar desconocida.

128 Pues «El tema de la Anunciación puede considerarse como sello distintivo de las iglesias financiadas por Fernán Pérez de Andrade o Boo, como también lo son el jabalí y su blasón (...)». MANSO PORTO; YZQUIERDO PERRÍN: 1996, op. cit., p. 346. 


\begin{tabular}{|c|c|c|c|c|c|c|}
\hline & & Ubicación & Cronología & Mano derecha & Mano izquierda & Indumentaria \\
\hline \multirow{18}{*}{ 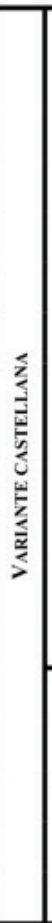 } & \multirow{13}{*}{ 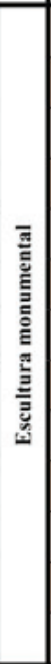 } & $\begin{array}{l}\text { Benavente (Zamora) } \\
\text { Iglesia de Santa Maria del Azogue }\end{array}$ & $\begin{array}{c}\text { s. XIV } \\
\text { principios }\end{array}$ & Sobre el vientre & $\begin{array}{c}\text { Modificada, restos } \\
\text { de filacteria }\end{array}$ & $\begin{array}{l}\text { Túnica, cingulo } \\
\text { y manto cruzado }\end{array}$ \\
\hline & & $\begin{array}{l}\text { Caleruega (Burgos) } \\
\text { Real Monasterio de Santo Domingo }\end{array}$ & $\begin{array}{l}\text { S. XIV } \\
I^{2} \text { mitad }\end{array}$ & Sobre el vientre & Filacteria & $\begin{array}{l}\text { Túnica, cíngulo } \\
\text { y manto cruzado }\end{array}$ \\
\hline & & $\begin{array}{l}\text { La Hiniesta (Zamora) } \\
\text { Iglesia de Santa Maria la Real }\end{array}$ & $\begin{array}{l}\text { S. XIV } \\
\text { principios }\end{array}$ & Sobre el vientre & Perdida & $\begin{array}{l}\text { Túnica, cingulo, manto cruzado, } \\
\text { velo cruzado y diadema }\end{array}$ \\
\hline & & $\begin{array}{l}\text { León (León) } \\
\text { Catedral }\end{array}$ & $\begin{array}{l}\text { s. XIII } \\
2^{2} \text { mitad }\end{array}$ & Sobre el vientre & Filacteria (rota) & $\begin{array}{l}\text { Túnica, cíngulo, manto cruzado, } \\
\text { velo cruzado y diadema }\end{array}$ \\
\hline & & $\begin{array}{l}\text { León (León) } \\
\text { Real Colegiata de San Isidoro }\end{array}$ & $\begin{array}{l}\text { s. XIII } \\
\text { finales }\end{array}$ & Sobre el vientre & Filacteria (rota) & $\begin{array}{l}\text { Túnica, cíngulo, manto cruzado, } \\
\text { velo cruzado y corona }\end{array}$ \\
\hline & & $\begin{array}{l}\text { Medina del Campo (Valladolid) } \\
\text { Iglesia de Santiago }\end{array}$ & $\begin{array}{l}\text { S. XIV } \\
2^{2} \text { mitad }\end{array}$ & Sobre el vientre & $\begin{array}{c}\text { Abierta, dirigida } \\
\text { hacia delante }\end{array}$ & Túnica, cíngulo y manto \\
\hline & & $\begin{array}{l}\text { Sasamón (Burgos) } \\
\text { Colegiata de Santa Maria la Real }\end{array}$ & - & $\begin{array}{l}\text { Perdida, zrestos de } \\
\text { filacteria? }\end{array}$ & Sobre el vientre & Túnica, manto cruzado y corona \\
\hline & & $\begin{array}{l}\text { Tarazona (Zaragoza) } \\
\text { Catedral }\end{array}$ & $\begin{array}{l}\text { 5. XIV } \\
\text { mediados }\end{array}$ & Sobre el vientre & Libro cerrado & $\begin{array}{l}\text { Túnica, cingulo } \\
\text { y manto cruzado }\end{array}$ \\
\hline & & $\begin{array}{l}\text { Toledo (Toledo) } \\
\text { Museo del Greco }\end{array}$ & $\begin{array}{l}\text { S. XIV } \\
1^{2} \text { mitad }\end{array}$ & Sobre el vientre & Filacteria & $\begin{array}{l}\text { Túnica, cíngulo, manto } \\
\text { cruzado y corona }\end{array}$ \\
\hline & & $\begin{array}{l}\text { Toro (Zamora) } \\
\text { Colegiata de Santa Maria la Mayor }\end{array}$ & $\begin{array}{l}\text { s. XIV } \\
\text { principios }\end{array}$ & Sobre el vientre & Filacteria (rota) & $\begin{array}{l}\text { Túnica, cíngulo, manto } \\
\text { cruzado y diadema }\end{array}$ \\
\hline & & $\begin{array}{l}\text { Valladolid (Valladolid) } \\
\text { Museo Diocesano y Catedralicio }\end{array}$ & $\begin{array}{c}\text { s. XIV } \\
2^{3} \text { mitad }\end{array}$ & Sobre el vientre & Recoge el manto & Túnica y manto cruzado \\
\hline & & $\begin{array}{l}\text { Valladolid (Valladolid) } \\
\text { Museo Nacional de Escultura }\end{array}$ & $\begin{array}{l}\text { s. XV } \\
\text { mediados }\end{array}$ & Sobre el vientre & Libro abierto & $\begin{array}{l}\text { Túnica abotonada, } \\
\text { cingulo y manto cruzado }\end{array}$ \\
\hline & & $\begin{array}{l}\text { Vitoria (Álava) } \\
\text { Catedral Vieja }\end{array}$ & $\begin{array}{l}\text { s. XIV } \\
\text { finales }\end{array}$ & Sobre el vientre & Perdida & $\begin{array}{l}\text { Túnica, cingulo } \\
\text { y manto cruzado }\end{array}$ \\
\hline & \multirow{5}{*}{ 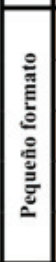 } & $\begin{array}{l}\text { Burgos (Burgos) } \\
\text { Catedral, sepulero de Lope de Fontecha }\end{array}$ & $\begin{array}{l}\text { s. XIV } \\
\text { finales }\end{array}$ & Sobre el vientre & Libro cerrado & Túnica y manto cruzado \\
\hline & & $\begin{array}{l}\text { Burgos (Burgos) } \\
\text { Catedral, sepulcro de Diaz de Peñaficl }\end{array}$ & $\begin{array}{l}\text { S. XIV } \\
1^{2} \text { mitad }\end{array}$ & Sobre el vientre & Libro cerrado & $\begin{array}{l}\text { Túnica, cíngulo } \\
\text { y manto cruzado }\end{array}$ \\
\hline & & $\begin{array}{l}\text { Laguardia ( }(\text { lalava) } \\
\text { Iglesia de Santa Maria de los Reyes }\end{array}$ & $\begin{array}{l}\text { s. XIV } \\
\text { finales }\end{array}$ & Sobre el vientre & Libro cerrado & Túnica, manto cruzado y velo \\
\hline & & $\begin{array}{l}\text { Oviedo (Asturias) } \\
\text { Catedral, capitel del claustro }\end{array}$ & $\begin{array}{l}\text { 5. XIV } \\
2^{2} \text { mitad }\end{array}$ & Sobre el vientre & Libro cerrado & Túnica y manto cruzado \\
\hline & & $\begin{array}{l}\text { Vitoria (Álava) } \\
\text { Catedral Vieja, timpano principal }\end{array}$ & $\begin{array}{c}\text { S. XIV } \\
2^{\circ} \text { tercio } \\
\end{array}$ & Sobre el vientre & Libro cerrado & $\begin{array}{l}\text { Túnica, cíngulo, manto } \\
\text { cruzado y velo cruzado }\end{array}$ \\
\hline \multirow{10}{*}{ 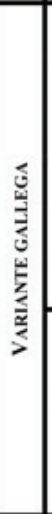 } & \multirow{6}{*}{ 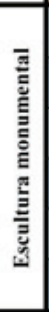 } & $\begin{array}{l}\text { Betanzos (A Coruña) } \\
\text { lglesia de San Francisco }\end{array}$ & - & Recoge el manto & Sobre el vientre & $\begin{array}{l}\text { Túnica abotonada, manto, } \\
\text { velo, corona y zapatos }\end{array}$ \\
\hline & & $\begin{array}{l}\text { Betanzos (A Coruña) } \\
\text { Iglesia de Santa Maria del Azogue }\end{array}$ & $\cdot$ & Recoge el manto & Sobre el vientre & $\begin{array}{l}\text { Túnica abotonada, manto } \\
\text { cruzado, velo, corona y zapatos }\end{array}$ \\
\hline & & $\begin{array}{l}\text { Santiago de Compostela (A Coruña) } \\
\text { Museo Catedral de Santiago }\end{array}$ & $\begin{array}{l}\text { s. XIV } \\
\text { os. XV }\end{array}$ & Alzada & Sobre el vientre & $\begin{array}{c}\text { Túnica abotonada, manto } \\
\text { cruzado, velo, broche y zapatos }\end{array}$ \\
\hline & & $\begin{array}{l}\text { Santiago de Compostela (A Coruña) } \\
\text { Iglesia de Santa Maria Salomé }\end{array}$ & - & Alzada & Sobre el vientre & $\begin{array}{l}\text { Túnica, manto cruzado, } \\
\text { velo, broche y zapatos }\end{array}$ \\
\hline & & $\begin{array}{l}\text { Tui (Pontevedra) } \\
\text { Catedral }\end{array}$ & $\begin{array}{l}\text { s. XIV } \\
\text { mediados }\end{array}$ & Alzada & Sobre el vientre & $\begin{array}{l}\text { Túnica abotonada } \\
\text { y manto cruzado }\end{array}$ \\
\hline & & $\begin{array}{l}\text { Verin (Ourense) Castillo de Monterrei, } \\
\text { iglesia de Santa Maria de Gracia }\end{array}$ & - & Alzada & Sobre el vientre & $\begin{array}{l}\text { Túnica, manto cruzado, } \\
\text { cingulo y zapatos }\end{array}$ \\
\hline & \multirow{4}{*}{ 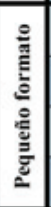 } & $\begin{array}{l}\text { Betanzos (A Coruna) San Francisco, } \\
\text { arcosolio sepulcral vacio con una Piedad }\end{array}$ & s. XV & Libro abierto & Sobre el vientre & Túnica, manto ¿cruzado? y velo \\
\hline & & $\begin{array}{l}\text { Betanzos (A Coruña) San Francisco, sepulcro } \\
\text { de un hombre con hábito franciscano }\end{array}$ & s. XV & Sobre el vientre & Libro ¿cerrado? & Túnica, manto cruzado y velo \\
\hline & & $\begin{array}{l}\text { Betanzos (A Cornuna) San Francisco, sepulcro } \\
\text { de dama de la familia de los Pardo y Aguilar }\end{array}$ & s. XV & Sobre el vientre & Libro abierto & Túnica, manto cruzado y velo \\
\hline & & $\begin{array}{l}\text { Noia ( } \Lambda \text { Coruña) } \\
\text { Iglesia de San Martín, timpano principal }\end{array}$ & $\begin{array}{l}\text { s. XIV } \\
\text { mediados }\end{array}$ & Alzada & Sobre el vientre & $\begin{array}{c}\text { Túnica, manto cruzado, } \\
\text { velo y zapatos }\end{array}$ \\
\hline \multirow{6}{*}{ 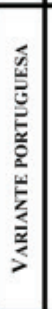 } & \multirow{6}{*}{. } & $\begin{array}{l}\text { Batalha (Leiria) } \\
\text { Monasterio de Santa Maria da Vitória }\end{array}$ & $\begin{array}{c}\text { s. XV } \\
\text { principios }\end{array}$ & Perdida & Sobre el vientre & $\begin{array}{l}\text { Túnica, manto cruzado, velo y } \\
\text { collar de manos }\end{array}$ \\
\hline & & $\begin{array}{l}\text { Évora (Évora) } \\
\text { Catedral }\end{array}$ & $\cdot$ & Alzada & $\begin{array}{l}\text { Sobre el vientre, } \\
\text { filacteria }\end{array}$ & $\begin{array}{l}\text { Túnica abotonada, manto } \\
\text { cruzado y corona }\end{array}$ \\
\hline & & $\begin{array}{l}\text { Évora (Évora) } \\
\text { Catedral, Capela do Fundador }\end{array}$ & $\begin{array}{l}\text { s. XIV } \\
\text { finales }\end{array}$ & - & - & - \\
\hline & & $\begin{array}{l}\text { Montemor-o-Velho (Coimbra) } \\
\text { Castillo, Iglesia Santa Maria de Alcáçova }\end{array}$ & s. XIV & Alzada & Sobre el vientre & $\begin{array}{l}\text { Túnica abotonada, ¿cingulo?, } \\
\text { manto, velo y broche }\end{array}$ \\
\hline & & $\begin{array}{l}\text { Samora Correira (Santarém) Iglesia de } \\
\text { Nossa Senhora da Oliveira, retablo pétreo }\end{array}$ & $\cdot$ & Sobre el vientre & Alzada & $\begin{array}{l}\text { Túnica abolonada, } \\
\text { manto y broche }\end{array}$ \\
\hline & & $\begin{array}{l}\text { Santarém (Santarém) Iglesia de Santa Clara, } \\
\text { sepulcro de Leonor Afonso }\end{array}$ & $\begin{array}{l}\text { 5. XIV } \\
1^{2} \text { mitad }\end{array}$ & Sobre el vientre & Alzada & Túnica y manto cruzado \\
\hline
\end{tabular}

Tabla 1. Cuadro comparativo de las Vírgenes de la Anunciación Preñada. 


\begin{tabular}{|c|c|c|c|c|c|c|}
\hline & & Ubicación & Cronología & Mano derecha & Mano izquierda & Indumentaria \\
\hline \multirow{18}{*}{ 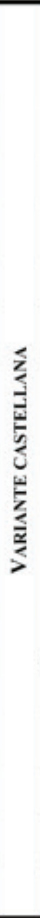 } & \multirow{13}{*}{ 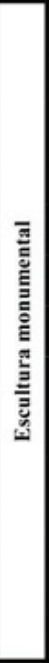 } & $\begin{array}{l}\text { Benavente (Zamora) } \\
\text { Iglesia de Santa Maria del Azogue }\end{array}$ & $\begin{array}{c}\text { s. XIV } \\
\text { principios }\end{array}$ & \multicolumn{2}{|c|}{ Posible filacteria sostenida } & Tủnica y capa pluvial \\
\hline & & $\begin{array}{l}\text { Caleruega (Burgos) } \\
\text { Real Monasterio de Santo Domingo }\end{array}$ & $\begin{array}{l}\text { s. XIV } \\
I^{2} \text { mitad }\end{array}$ & \multicolumn{2}{|c|}{ Filacteria } & Túnica y capa pluvial \\
\hline & & $\begin{array}{l}\text { La Hiniesta (Zamora) } \\
\text { Iglesia de Santa Maria la Real }\end{array}$ & $\begin{array}{l}\text { s. XIV } \\
\text { principios }\end{array}$ & \multicolumn{2}{|c|}{ Perdidas } & - \\
\hline & & $\begin{array}{l}\text { León (León) } \\
\text { Catedral }\end{array}$ & $\begin{array}{l}\text { s. XIII } \\
2^{n} \text { mitad }\end{array}$ & \multicolumn{2}{|c|}{ Filacteria (rota) } & Túnica y capa pluvial \\
\hline & & $\begin{array}{l}\text { León (León) } \\
\text { Real Colegiata de San Isidoro }\end{array}$ & $\begin{array}{l}\text { s. XIII } \\
\text { finales }\end{array}$ & \multicolumn{2}{|c|}{ Filacteria (rota) } & Túnica y capa pluvial \\
\hline & & $\begin{array}{l}\text { Medina del Campo (Valladolid) } \\
\text { Iglesia de Santiago }\end{array}$ & $\begin{array}{l}\text { S. XIV } \\
2^{a} \text { mitad }\end{array}$ & \multicolumn{3}{|c|}{ Desaparecido } \\
\hline & & $\begin{array}{l}\text { Sasamón (Burgos) } \\
\text { Colcgiata de Santa Maria la Real }\end{array}$ & $\cdot$ & \multicolumn{2}{|c|}{ Filacteria } & Túnica y capa pluvial \\
\hline & & $\begin{array}{l}\text { Tarazona (Zaragoza) } \\
\text { Catedral }\end{array}$ & $\begin{array}{l}\text { s. XIV } \\
\text { mediados }\end{array}$ & \multicolumn{2}{|c|}{ Filacteria } & - \\
\hline & & $\begin{array}{l}\text { Toledo (Toledo) } \\
\text { Museo del Greco }\end{array}$ & $\begin{array}{l}\text { s. XIV } \\
1^{2} \text { mitad }\end{array}$ & \multicolumn{2}{|c|}{ Filacteria } & Túnica y capa pluvial \\
\hline & & $\begin{array}{l}\text { Toro (Zamora) } \\
\text { Colegiata de Santa Maria la Mayor }\end{array}$ & $\begin{array}{l}\text { s. XIV } \\
\text { principios }\end{array}$ & \multicolumn{2}{|c|}{ Filacteria } & Túnica y capa pluvial \\
\hline & & $\begin{array}{l}\text { Valladolid (Valladolid) } \\
\text { Museo Diocesano y Catedralicio }\end{array}$ & $\begin{array}{l}\text { s. XIV } \\
2^{a} \text { mitad }\end{array}$ & \multicolumn{2}{|c|}{ - } & - \\
\hline & & $\begin{array}{l}\text { Valladolid (Valladolid) } \\
\text { Museo Nacional de Escultura }\end{array}$ & $\begin{array}{l}\text { s. XV } \\
\text { mediados }\end{array}$ & \multicolumn{2}{|c|}{ Perdidas } & - \\
\hline & & $\begin{array}{l}\text { Vitoria (Álava) } \\
\text { Catedral Vieja } \\
\end{array}$ & $\begin{array}{l}\text { s. XIV } \\
\text { finales } \\
\end{array}$ & \multicolumn{2}{|c|}{ Perdidas } & Alba, dalmática y casulla \\
\hline & \multirow{5}{*}{ 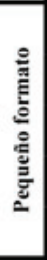 } & $\begin{array}{l}\text { Burgos (Burgos) } \\
\text { Catedral, sepulcro de Lope de Fontecha }\end{array}$ & $\begin{array}{l}\text { 5. XIV } \\
\text { finales }\end{array}$ & IIacia Maria & Filacteria & Túnica y manto \\
\hline & & $\begin{array}{l}\text { Burgos (Burgos) } \\
\text { Catedral, scpulcro de Diaz de Per̀aficl }\end{array}$ & $\begin{array}{l}\text { S. XIV } \\
I^{2} \text { mitad }\end{array}$ & Hacia Maria & Perdida & Túnica y manto \\
\hline & & $\begin{array}{l}\text { Laguardia (Álava) } \\
\text { Iglesia de Santa Maria de los Reyes } \\
\end{array}$ & $\begin{array}{l}\text { 5. XIV } \\
\text { finales }\end{array}$ & Perdida & Filacteria & Túnica y manto \\
\hline & & $\begin{array}{l}\text { Oviedo (Asturias) } \\
\text { Catedral, capitel del claustro }\end{array}$ & $\begin{array}{l}\text { S. XIV } \\
2^{a} \text { mitad }\end{array}$ & Hacia Maria & Filacteria & Túnica y manto \\
\hline & & $\begin{array}{l}\text { Vitoria (Álava) } \\
\text { Catedral Vieja, timpano principal }\end{array}$ & $\begin{array}{l}\text { 5. XIV } \\
2^{\circ} \text { tercio }\end{array}$ & \multicolumn{2}{|c|}{ Perdidas } & Tủnica y manto \\
\hline \multirow{10}{*}{ 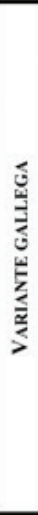 } & \multirow{6}{*}{ 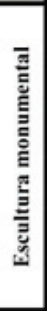 } & $\begin{array}{l}\text { Betanzos (A Coruña) } \\
\text { Iglesia de San Francisco }\end{array}$ & $\cdot$ & Hacia María & Filacteria & Alba y dalmática \\
\hline & & $\begin{array}{l}\text { Betanzos (A Coruña) } \\
\text { Iglesia de Santa Maria del Azogue }\end{array}$ & - & \multicolumn{2}{|c|}{ Filacteria } & Alba, dalmática y manípulo \\
\hline & & $\begin{array}{l}\text { Santiago de Compostela (A Coruña) } \\
\text { Museo Catedral de Santiago }\end{array}$ & $\begin{array}{l}\text { s. XIV } \\
\text { o s. XV }\end{array}$ & \multicolumn{2}{|c|}{ Filacteria } & Alba y dalmática y manipulo \\
\hline & & $\begin{array}{l}\text { Santiago de Compostela (A Coruña) } \\
\text { Iglesia de Santa Maria Salomé }\end{array}$ & $\cdot$ & \multicolumn{2}{|c|}{ Filacteria } & Alba, dalmática y manipulo \\
\hline & & $\begin{array}{l}\text { Tui (Pontevedra) } \\
\text { Catedral }\end{array}$ & $\begin{array}{l}\text { s. XIV } \\
\text { mediados }\end{array}$ & \multicolumn{2}{|c|}{ Filacteria } & Alba y dalmática \\
\hline & & $\begin{array}{l}\text { Verin (Ourense) Castillo de Monterrei, } \\
\text { iglesia de Santa Maria de Gracia }\end{array}$ & - & \multicolumn{2}{|c|}{ Filacteria } & Alba y dalmática \\
\hline & 를 & $\begin{array}{l}\text { Betanzos (A Coruna) San Francisco, } \\
\text { arcosolio sepulcral vacio con una Piedad }\end{array}$ & s. XV & \multicolumn{2}{|c|}{ Filacteria } & Alba y dalmática \\
\hline & อ & $\begin{array}{l}\text { Betanzos (A Coruña) San Francisco, sepulcro } \\
\text { de un hombre con hábito franciscano }\end{array}$ & s. XV & \multicolumn{2}{|c|}{ Filacteria } & Alba y dalmática \\
\hline & 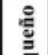 & $\begin{array}{l}\text { Betanzos ( } A \text { Coruña) San Francisco, sepulcro } \\
\text { de dama de la familia de los Pardo y Aguilar }\end{array}$ & s. XV & \multicolumn{2}{|c|}{ Filacteria } & Alba y dalmática \\
\hline & $\stackrel{\bar{z}}{2}$ & $\begin{array}{l}\text { Noia ( } \Lambda \text { Coruña) } \\
\text { Iglesia de San Martín, tímpano principal }\end{array}$ & $\begin{array}{l}\text { s. XIV } \\
\text { mediados }\end{array}$ & \multicolumn{2}{|c|}{ Filacteria } & Nlba y dalmática \\
\hline & & $\begin{array}{l}\text { Batalha (Leiria) } \\
\text { Monasterio de Santa Maria da Vitória }\end{array}$ & $\begin{array}{c}\text { s. XV } \\
\text { principios }\end{array}$ & Simétrica & Filacteria & Túnica \\
\hline 空 & & $\begin{array}{l}\text { Evora (Évora) } \\
\text { Catedral }\end{array}$ & - & Alzada & Objeto & Túnica y capa pluvial \\
\hline$\frac{\sqrt{2}}{0}$ & & $\begin{array}{l}\text { Évora (Évora) } \\
\text { Catedral, Capela do Fundador }\end{array}$ & $\begin{array}{l}\text { s. XIV } \\
\text { finales }\end{array}$ & - & - & - \\
\hline$\frac{2}{2}$ & ' & $\begin{array}{l}\text { Montemor-0-Velho (Coimbra) } \\
\text { Castillo, Iglesia Santa Maria de Alcáçova }\end{array}$ & s. XIV & Fil & teria & Túnica y manto \\
\hline 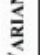 & & $\begin{array}{l}\text { Samora Correira (Santarém) Iglesia de } \\
\text { Nossa Senhora da Oliveira, retablo pétreo }\end{array}$ & - & Hacia Maria & Perdida & Túnica y manto \\
\hline & & $\begin{array}{l}\text { Santarém (Santarém) Iglesia de Santa Clara, } \\
\text { sepulcro de Leonor Afonso }\end{array}$ & $\begin{array}{l}\text { s. XIV } \\
1^{a} \text { mitad }\end{array}$ & & teria & Túnica y manto \\
\hline
\end{tabular}

Tabla 2. Cuadro comparativo de los arcángeles de la Anunciación Preñada. 